\title{
Semi-continuous gas and inorganic aerosol measurements at a Finnish urban site: comparisons with filters, nitrogen in aerosol and gas phases, and aerosol acidity
}

\author{
U. Makkonen ${ }^{1}$, A. Virkkula ${ }^{1,2}$, J. Mäntykenttä ${ }^{1}$, H. Hakola ${ }^{1}$, P. Keronen ${ }^{2}$, V. Vakkari ${ }^{2}$, and P. P. Aalto ${ }^{2}$ \\ ${ }^{1}$ Finnish Meteorological Institute, 00560, Helsinki, Finland \\ ${ }^{2}$ University of Helsinki, 00560, Helsinki, Finland \\ Correspondence to: U. Makkonen (ulla.makkonen@fmi.fi)
}

Received: 5 January 2012 - Published in Atmos. Chem. Phys. Discuss.: 10 February 2012

Revised: 23 May 2012 - Accepted: 3 June 2012 - Published: 28 June 2012

\begin{abstract}
Concentrations of 5 gases $\left(\mathrm{HCl}, \mathrm{HNO}_{3}, \mathrm{HONO}\right.$, $\left.\mathrm{NH}_{3}, \mathrm{SO}_{2}\right)$ and 8 major inorganic ions in particles $\left(\mathrm{Cl}^{-}\right.$, $\mathrm{NO}_{3}^{-}, \mathrm{SO}_{4}^{2-}, \mathrm{NH}_{4}^{+}, \mathrm{Na}^{+}, \mathrm{K}^{+}, \mathrm{Mg}^{2+}, \mathrm{Ca}^{2+}$ ) were measured with an online monitor MARGA $2 \mathrm{~S}$ in two size ranges, $D_{\mathrm{p}}$ $<2.5 \mu \mathrm{m}$ and $D_{\mathrm{p}}<10 \mu \mathrm{m}$, in Helsinki, Finland from November 2009 to May 2010. The results were compared with filter sampling, mass concentrations obtained from particle number size distributions, and a conventional $\mathrm{SO}_{2}$ monitor. The MARGA yielded lower concentrations than those analyzed from the filter samples for most ions. Linear regression yielded the following MARGA vs. filter slopes: 0.72 for $\mathrm{Cl}^{-}, 0.90$ for $\mathrm{NO}_{3}^{-}, 0.85$ for $\mathrm{SO}_{4}^{2-}, 0.91$ for $\mathrm{NH}_{4}^{+}, 0.49$ for $\mathrm{Na}^{+}, 3.0$ for $\mathrm{Mg}^{2+}$, and 3.0 for $\mathrm{Ca}^{2+}$ and 0.90 for the MARGA vs. $\mathrm{SO}_{2}$ monitor. For $\mathrm{K}^{+}$there were not enough data points to calculate a statistically significant linear regression. There were clear seasonal cycles in the concentrations of the nitrogen-containing gases: the median concentrations of $\mathrm{HNO}_{3}, \mathrm{HONO}$, and $\mathrm{NH}_{3}$ were $0.09 \mathrm{ppb}, 0.37 \mathrm{ppb}$, and $0.01 \mathrm{ppb}$ in winter, respectively, and $0.15,0.15$, and 0.14 in spring, respectively. The gas-phase fraction of nitrogen decreased roughly with decreasing temperature, so that in the coldest period from January to February the median contribution was $28 \%$ but in April to May was $53 \%$. There were also large fractionation variations that temperature alone cannot explain. $\mathrm{HONO}$ correlated well with $\mathrm{NO}_{\mathrm{x}}$ but a large fraction of the HONO-to- $\mathrm{NO}_{\mathrm{x}}$ ratios were larger than published ratios in a road traffic tunnel, suggesting that a large amount of HONO had other sources than vehicle exhaust. Aerosol acidity was estimated by calculating ion equivalent ratios. The sources of acidic aerosols were studied with trajectory
\end{abstract}

statistics that showed that continental aerosol is mainly neutralized and marine aerosol acidic.

\section{Introduction}

Concentrations of major inorganic ions in aerosols have been measured for decades by sampling on filters and subsequently analyzing them with ion chromatography (e.g., $\mathrm{Mu}$ lik et al., 1976; Stevens et al., 1978; Mulik and Sawicki, 1979). These kind of measurements are an integral part of monitoring networks such as the European Monitoring and Evaluation Programme (EMEP) (EMEP, 2007). With filter sampling, time resolution is low - from some hours to days depending on concentrations. In addition, filter sampling suffers from both negative and positive artifacts (e.g., Lipfert, 1994). In order to study atmospheric processes, methods have been developed for measuring aerosol chemical composition at a higher time resolution and to avoid the artifacts associated with filter sampling.

A method with a good time resolution, in the order of seconds/minutes, is the Aerosol Mass Spectrometer (AMS) (Jayne et al., 2000; Jimenez et al., 2003), which provides size-resolved chemical composition of submicron aerosols. The AMS measures the concentrations of major aerosol constituents: organics, sulphate, nitrate, ammonium, and chloride. The disadvantage of it is that it does not detect some other important elements such as sodium, one of the main constituents of sea salt, and calcium and magnesium, significant constituents of both both soil dust and sea salt. To 
analyze these elements, semicontinuous methods involving ion chromatography have been developed. In these methods, the sample is first taken for a period of some minutes to hours and then analyzed. An example is the Particle Into Liquid Sampler (PILS) that can be connected, for instance, to an ion chromatograph (IC) or an instrument for analyzing the concentration of water-soluble organic carbon (Weber et al., 2001; Orsini et al., 2003; Sullivan et al., 2004). The PILS combines two aerosol technologies: particle growth in a mixing condensation particle counter, and droplet collection by a single jet inertial impactor. It takes advantage of the principle of steam-jet aerosol collector (SJAC) (e.g., Khlystov et al., 1995). Another semicontinuous method that uses a SJAC is the ambient ion monitor (AIM, URG Corporation, USA) that determines the concentrations of several anions and cations in aerosol (e.g., Wu and Wang, 2007; Nie et al., 2010) and exists in four different configurations (URG 9000A-D) that have different performances. Yet another method that is based on the same principle is the Dionex Gas Particle Ion Chromatography (GPIC) system that measures concentrations of water-soluble inorganic aerosol constituents $\left(\mathrm{Cl}^{-}\right.$, $\mathrm{NO}_{3}^{-}, \mathrm{SO}_{4}^{2-}$, and $\mathrm{NH}_{4}^{+}$) and their associated precursor gases $\left(\mathrm{HCl}, \mathrm{SO}_{2}, \mathrm{HNO}_{3}, \mathrm{NH}_{3}\right.$ ) (Godri et al., 2009). The ability to measure both water-soluble aerosol and the precursor gas concentrations at a high time resolution has recently been shown to be especially valuable for evaluating models, for instance the secondary inorganic aerosol formation (Schaap et al., 2011) and the gas-aerosol partitioning of ammonium nitrate (Aan de Brugh et al., 2012).

For measuring ammonia, several methods have been developed based on very different principles: wet chemistry, optics, optoacoustics and mass specrometric techniques. An intercomparison of eleven instruments for measuring atmospheric ammonia at ambient concentrations was presented by von Bobrutzki et al. (2010). It was shown in that paper that wet chemistry instruments had good long-term stability and provided a reliable differentiation between gas-phase $\mathrm{NH}_{3}$ and aerosol $\mathrm{NH}_{4}^{+}$, which could not be validated for the other instruments.

The instrument for Measuring AeRosols and GAses (MARGA) (ten Brink et al., 2007) has a SJAC (Slanina et al., 2001) and it is connected to two ion chromatographs, one for anions and another for cations. In addition, it also measures the concentrations of water-soluble gases that produce ions observable with an IC, using the principles presented, e.g., by Wyers et al. (1993). Trebs et al. (2004) who used basically the same method, even though they did not call it MARGA then, at a rural site in the Amazon Basin. The instrument consisted of a wet rotating annular denuder in combination with a SJAC, followed by an IC for measuring anions and flow injection analysis (FIA) for measuring ammonium; other cations were not measured. The MARGA was used to monitor the size distribution of nitrate, ammonium, sulphate and chloride in aerosol at the top of a 200-m meteotower in Cabauw, Netherlands (ten Brink et al., 2007). Four parallel impactors with cut-offs of $0.18,0.32,0.56$ and $1.0 \mu$ $\mathrm{m}$ were attached to the MARGA inlet. In a clean background environment, a MARGA was used at an EMEP supersite in Scotland (Cape, 2009).

A commercially available MARGA (Applikon Analytical BV, Netherlands) was operated by the Finnish Meteorological Institute Air Quality Research (FMI/AQR) at the urban background station in Kumpula, Helsinki, from November 2009 to May 2010. These were the first semi-continuous measurements of sulphur dioxide $\left(\mathrm{SO}_{2}\right)$, nitric acid $\left(\mathrm{HNO}_{3}\right)$, nitrous acid $\left(\mathrm{HNO}_{2}\right.$ or $\left.\mathrm{HONO}\right)$, hydrochloric acid $(\mathrm{HCl})$ and ammonia $\left(\mathrm{NH}_{3}\right)$ using a rotating wet annular denuder in combination with an on-line ion chromatograph in Finland. In addition, the major anion $\left(\mathrm{Cl}^{-}, \mathrm{NO}_{3}^{-}, \mathrm{SO}_{4}^{2-}\right)$ and cation $\left(\mathrm{NH}_{4}^{+}, \mathrm{Na}^{+}, \mathrm{K}^{+}, \mathrm{Mg}^{2+}, \mathrm{Ca}^{2+}\right)$ concentrations in aerosols in two size ranges, $D_{\mathrm{p}}<2.5 \mu \mathrm{m}\left(\mathrm{PM}_{2.5}\right)$ and $D_{\mathrm{p}}<10 \mu \mathrm{m}$ $\left(\mathrm{PM}_{10}\right)$, were measured with the instrument.

The most important goal of this study was to investigate whether the MARGA could be used to replace the traditional EMEP filter pack method (EMEP, 2007). Furthermore, the Clean Air for Europe (CAFE) Directive (EU 2008/50/EC) demands that the member states measure also the chemical composition of $\mathrm{PM}_{2.5}$. For monitoring networks it is important that the measurement methods give comparable results. There are published comparisons between filter sampling and semicontinuous methods (e.g., Nie et al., 2010) but not with the commercially available MARGA. Trebs et al. (2008) compared Amazonian ammonium, nitrate, chloride, and sulphate concentrations analyzed from filter samples with those measured with an instrument similar to MARGA. In the comparison, ammonium was the only cation, and in that instrument it was analyzed with FIA. In the instrument used in the present work, five cations were analyzed, all with an IC. To our knowledge, there are no published comparisons between a MARGA that analyzes the concentrations of all the abovementioned three anions and five cations and conventional filter sampling methods.

In this paper the performance of the MARGA $2 \mathrm{~S}$ instrument is first evaluated by comparing it with independent methods: filter sampling, mass concentrations obtained from particle number size distributions, and a conventional $\mathrm{SO}_{2}$ monitor. Next, the observations on nitrogen compounds (both in the gas and aerosol phases) are discussed, and finally the aerosol data are used to study aerosol acidity and its sources.

\section{Experimental}

\subsection{Measurement site}

The Station for Measuring Ecosystem-Atmosphere Relationships (SMEAR III) is located next to the main building of the Finnish Meteorological Institute (FMI) on a rocky hill $26 \mathrm{~m}$ a.s.l., about $5 \mathrm{~km}$ northeast of the center of Helsinki. The station consists of a measurement container 
and meteorological measurements on ground and in a tower. The container is air conditioned and kept at a constant temperature at $20^{\circ} \mathrm{C}$. A comprehensive description of the SMEAR III station can be found in Järvi et al. (2009).

\subsection{MARGA}

Concentrations of 5 gases $\left(\mathrm{HCl}, \mathrm{HNO}_{3}, \mathrm{HONO}, \mathrm{NH}_{3}\right.$, $\left.\mathrm{SO}_{2}\right)$ and 8 major inorganic ions in particles $\left(\mathrm{Cl}^{-}, \mathrm{NO}_{3}^{-}\right.$, $\mathrm{SO}_{4}^{2-}, \mathrm{NH}_{4}^{+}, \mathrm{Na}^{+}, \mathrm{K}^{+}, \mathrm{Mg}^{2+}, \mathrm{Ca}^{2+}$ ) were measured with a MARGA 2S from 1 November 2009 to 24 May 2010. The MARGA 2S ADI 2080 (Applikon Analytical BV, Netherlands) consists of two identical sample boxes and one analytical box. Ambient air was drawn at the flow rate of $2 \mathrm{~m}^{3} \mathrm{~h}^{-1}$ through a $\mathrm{PM}_{10}$-inlet (Teflon coated, URG-200030DBN-TC, $2 \mathrm{~m}^{3} \mathrm{~h}^{-1}$ ) and devided into the $\mathrm{PM}_{10}$ sample box and into the $\mathrm{PM}_{2.5}$ sample box through a $\mathrm{PM}_{2.5}$ cyclone $\left(1 \mathrm{~m}^{3} \mathrm{~h}^{-1}\right.$ Teflon coated inlet, URG-2000-30ENB). However, the first part of the measurements (1 November 200919 January 2010) was carried out without any specific inlet - there was just a rain shield on the inlet tubing. The $\mathrm{PM}_{10}$-inlet and the $\mathrm{PM}_{2.5}$ cyclone were installed on 19 January 2010.

Sample air was first drawn through the Wet Rotating Denuder (WRD) where water-soluble gases diffused to the absorption solution, then particles were collected in a steam-jet aerosol collector (SJAC) (Slanina et al., 2001). Diluted hydrogen peroxide solution (10 ppm) was used as the absorption solution to prevent microbiological growth. Absorption solutions were drawn from the WRD and the SJAC to syringes $(25 \mathrm{ml})$ in the analytical box. Each hour after the syringes had been filled, samples were injected to Metrohm anion $(250 \mu$ l loop) and cation ( $500 \mu$ l loop) chromatographs with the internal standard ( $\mathrm{LiBr})$. Cations were separated in a Metrosep C4 (100/4.0) cation column using $3.2 \mathrm{mmol}^{-1}$ $\mathrm{HNO}_{3}$ eluent. For anions a Metrosep A Supp 10 (75/4.0) column and $\mathrm{Na}_{2} \mathrm{CO}_{3}-\mathrm{NaHCO}_{3}\left(7 / 8 \mathrm{mmol}^{-1}\right)$ eluent was used. Components were detected by conductivity measurements. For anions a chemical suppressor $\left(\mathrm{H}_{3} \mathrm{PO}_{4}\right.$ for regeneration) was used. The detection limits for all the components were $0.1 \mu \mathrm{g} \mathrm{m}^{-3}$ or better, except for $\mathrm{K}^{+}\left(0.16 \mu \mathrm{g} \mathrm{m}^{-3}\right), \mathrm{Mg}^{2+}$ $\left(0.12 \mu \mathrm{g} \mathrm{m}^{-3}\right)$ and $\mathrm{Ca}^{2+}\left(0.21 \mu \mathrm{g} \mathrm{m}^{-3}\right)$. The detection limits and the repeatability of the instrument studied from parallel measurements of the two sample boxes (neither the $\mathrm{PM}_{10^{-}}$ inlet nor $\mathrm{PM}_{2.5}$ cyclone was used) are presented in Table 1 .

Field blanks for gases were checked by installing filters in the sampling line before the denuder of the instrument. An oxalic-acid-impregnated filter was used to remove ammonia and a $\mathrm{NaOH}$ impregnated filter to remove acidic gases. The blank values for gases were insignificant, except for nitric acid. The instrument blank for nitrate and nitric acid was remarkable, of the order of $0.4 \mu \mathrm{g} \mathrm{m}^{-3}$, and the blank-value caused by the instrument was subtracted from the results. The high nitrate blank was caused by small amounts of cation eluent leaking continuously to the anion injector.
Table 1. The detection limits and the repeatability calculated from real air samples collected using the two parallel sample boxes of the MARGA instrument (1 November 2009-18 January 2010).

\begin{tabular}{lcc}
\hline Compound & $\begin{array}{c}\text { Detection limit } \\
\mu \mathrm{g} \mathrm{m}^{-3}\end{array}$ & $\begin{array}{c}\text { Repeatability } \\
\%\end{array}$ \\
\hline $\mathrm{HCl}$ & 0.02 & 30 \\
$\mathrm{HNO}_{2}$ & 0.03 & 3.3 \\
$\mathrm{SO}_{2}$ & 0.04 & 4.9 \\
$\mathrm{HNO}_{3}$ & 0.05 & 1.1 \\
$\mathrm{NH}_{3}$ & 0.05 & 3.9 \\
$\mathrm{Cl}^{-}$ & 0.02 & 4.5 \\
$\mathrm{NO}_{3}^{-}$ & 0.04 & 1.0 \\
$\mathrm{SO}_{4}^{2-}$ & 0.03 & 1.1 \\
$\mathrm{Na}^{+}$ & 0.02 & 1.2 \\
$\mathrm{NH}_{4}^{+}$ & 0.03 & 1.9 \\
$\mathrm{~K}^{+}$ & 0.01 & 13 \\
$\mathrm{Mg}^{2+}$ & 0.01 & 8.7 \\
$\mathrm{Ca}^{2+}$ & 0.01 & 1.1 \\
\hline
\end{tabular}

\subsection{Filter sampling}

The aerosol results of MARGA were compared with the results of daily sampling of $\mathrm{PM}_{10}$ (Digitel $\mathrm{PM}_{10}$ sampling inlet, $1 \mathrm{~m}^{3} \mathrm{~h}^{-1}$ ) and $\mathrm{PM}_{2.5}\left(\right.$ Digitel $\mathrm{PM}_{2.5}$ inlet, $1 \mathrm{~m}^{3} \mathrm{~h}^{-1}$ ) on Teflon filters. The filters were extracted in ultrapure water (Milli-Q) and analyzed by ion chromatographs (Waters). The procedure is described in detail in the EMEP Manual (EMEP, 2007). Daily averages were calculated from the MARGA results and compared with the results of the filter method from 5 February to 5 May 2010.

\subsection{Other measurements}

The routine measurements of the SMEAR III station include particle number size distribution measurements with a Twin DMPS (TDMPS) in the size range 3-950 nm: $\mathrm{SO}_{2}$ measurements with a Horiba APSA 360 monitor; $\mathrm{O}_{3}$ measurements with a TEI 49 monitor; and $\mathrm{NO}_{\mathrm{x}}$ measurements with a TEI $42 \mathrm{~S}$ monitor. There is also other instrumentation at the site (see Järvi et al. (2009) for details) but those mentioned above are used here. The number size distributions were used for estimating submicron aerosol mass concentration and comparing that with the sum of the analyzed ions. The $\mathrm{SO}_{2}$ concentrations could be used as such since the MARGA also measures it. The $\mathrm{NO}_{\mathrm{x}}$ and ozone concentrations were used for studies of nitric and nitrous acid.

\section{Results and discussion}

A statistical summary of the MARGA data is presented in Table 2, including averages, standard deviations, selected 
Table 2. Statistical summary of the MARGA data measured at SMEAR III station in Helsinki in winter (1 November 2009-28 February 2010) and in spring (1 March-25 May 2010). Five first columns: concentrations of gases in ppb and of aerosols in the two size fractions in $\mu \mathrm{g} \mathrm{m}^{-3}$ at $20^{\circ} \mathrm{C}, 1013 \mathrm{mbar} ; N / N_{\text {tot }}$ : fraction of total number of hours during which there is data for the compound; $N / N_{\text {tot }}(C>\mathrm{DL})$ : fraction of total number of hours during which concentration was above detection limit. The winter $\mathrm{PM}_{2.5}$ statistics were calculated for the period 19 January-28 February in winter $N_{\text {tot }}=2879$ for $\mathrm{PM}_{10}$ and 919 for $\mathrm{PM}_{2.5}$; in spring $N_{\text {tot }}=2047$ for both $\mathrm{PM}_{2.5}$ and $\mathrm{PM}_{10}$.

\begin{tabular}{|c|c|c|c|c|c|c|c|c|c|c|c|c|c|}
\hline & & \multicolumn{6}{|c|}{ WINTER } & \multicolumn{6}{|c|}{ SPRING } \\
\hline & & \multirow[b]{2}{*}{$\mathrm{AVE} \pm \mathrm{STD}$} & \multicolumn{3}{|c|}{ Percentiles } & \multirow[b]{2}{*}{$N / N_{\text {tot }}$} & \multirow[b]{2}{*}{$N / N_{\text {tot }}(C>\mathrm{DL})$} & \multirow[b]{2}{*}{$\mathrm{AVE} \pm \mathrm{STD}$} & \multicolumn{3}{|c|}{ Percentiles } & \multirow[b]{2}{*}{$N / N_{\text {tot }}$} & \multirow[b]{2}{*}{$N / N_{\text {tot }}(C>\mathrm{DL})$} \\
\hline & & & 2.5 & 50 & 97.5 & & & & 2.5 & 50 & 97.5 & & \\
\hline $\mathrm{HNO}_{3}$ & & $0.13 \pm 0.12$ & 0.03 & 0.09 & 0.38 & $90 \%$ & $90 \%$ & $0.22 \pm 0.19$ & 0.06 & 0.15 & 0.72 & $85 \%$ & $85 \%$ \\
\hline $\mathrm{HNO}_{2}$ & & $0.45 \pm 0.33$ & 0.11 & 0.37 & 1.18 & $91 \%$ & $91 \%$ & $0.19 \pm 0.14$ & 0.04 & 0.15 & 0.64 & $84 \%$ & $84 \%$ \\
\hline $\mathrm{NH}_{3}$ & & $0.25 \pm 0.44$ & 0.01 & 0.01 & 1.33 & $92 \%$ & $92 \%$ & $0.28 \pm 0.41$ & 0.01 & 0.14 & 1.61 & $85 \%$ & $85 \%$ \\
\hline $\mathrm{SO}_{2}$ & & $1.32 \pm 1.73$ & 0.10 & 0.65 & 6.54 & $92 \%$ & $92 \%$ & $0.76 \pm 1.00$ & 0.11 & 0.47 & 3.38 & $85 \%$ & $85 \%$ \\
\hline $\mathrm{HCl}$ & & $0.03 \pm 0.08$ & $<\mathrm{DL}$ & $<\mathrm{DL}$ & 0.18 & $84 \%$ & $36 \%$ & $0.04 \pm 0.11$ & $<\mathrm{DL}$ & $<\mathrm{DL}$ & 0.25 & $85 \%$ & $29 \%$ \\
\hline \multirow[t]{2}{*}{$\mathrm{Cl}^{-}$} & $\mathrm{PM}_{2.5}$ & $0.10 \pm 0.25$ & $<\mathrm{DL}$ & 0.03 & 0.62 & $96 \%$ & $56 \%$ & $0.04 \pm 0.14$ & $<\mathrm{DL}$ & 0.01 & 0.28 & $85 \%$ & $17 \%$ \\
\hline & $\mathrm{PM}_{10}$ & $0.11 \pm 0.26$ & $<\mathrm{DL}$ & 0.02 & 0.73 & $84 \%$ & $45 \%$ & $0.08 \pm 0.23$ & $<\mathrm{DL}$ & 0.01 & 0.59 & $85 \%$ & $25 \%$ \\
\hline \multirow{2}{*}{$\mathrm{NO}_{3}^{-}$} & $\mathrm{PM}_{2.5}$ & $2.27 \pm 1.76$ & 0.23 & 1.87 & 7.41 & $96 \%$ & $95 \%$ & $1.40 \pm 2.04$ & 0.14 & 0.68 & 7.34 & $84 \%$ & $84 \%$ \\
\hline & $\mathrm{PM}_{10}$ & $1.50 \pm 1.45$ & 0.15 & 1.09 & 5.58 & $91 \%$ & $91 \%$ & $1.63 \pm 2.24$ & 0.18 & 0.89 & 8.27 & $84 \%$ & $84 \%$ \\
\hline \multirow[t]{2}{*}{$\mathrm{SO}_{4}^{2-}$} & $\mathrm{PM}_{2.5}$ & $3.18 \pm 1.23$ & 1.39 & 2.93 & 5.78 & $96 \%$ & $96 \%$ & $1.64 \pm 1.08$ & 0.37 & 1.45 & 4.39 & $84 \%$ & $84 \%$ \\
\hline & $\mathrm{PM}_{10}$ & $2.15 \pm 1.38$ & 0.43 & 1.76 & 5.70 & $92 \%$ & $92 \%$ & $1.79 \pm 1.24$ & 0.41 & 1.53 & 4.88 & $85 \%$ & $85 \%$ \\
\hline \multirow[t]{2}{*}{$\mathrm{Na}^{+}$} & $\mathrm{PM}_{2.5}$ & $0.05 \pm 0.08$ & $<\mathrm{DL}$ & 0.02 & 0.30 & $96 \%$ & $50 \%$ & $0.04 \pm 0.11$ & $<\mathrm{DL}$ & 0.01 & 0.40 & $80 \%$ & $17 \%$ \\
\hline & $\mathrm{PM}_{10}$ & $0.08 \pm 0.17$ & $<\mathrm{DL}$ & 0.03 & 0.57 & $92 \%$ & $50 \%$ & $0.07 \pm 0.18$ & $<\mathrm{DL}$ & 0.01 & 0.57 & $80 \%$ & $26 \%$ \\
\hline \multirow[t]{2}{*}{$\mathrm{NH}_{4}^{+}$} & $\mathrm{PM}_{2.5}$ & $0.74 \pm 0.65$ & $<\mathrm{DL}$ & 0.59 & 2.55 & $96 \%$ & $93 \%$ & $0.46 \pm 0.80$ & $<\mathrm{DL}$ & 0.19 & 2.71 & $85 \%$ & $70 \%$ \\
\hline & $\mathrm{PM}_{10}$ & $0.55 \pm 0.54$ & $<\mathrm{DL}$ & 0.41 & 1.95 & $92 \%$ & $84 \%$ & $0.49 \pm 0.86$ & $<\mathrm{DL}$ & 0.20 & 2.90 & $84 \%$ & $71 \%$ \\
\hline \multirow[t]{2}{*}{$\mathrm{K}^{+}$} & $\mathrm{PM}_{2.5}$ & $0.04 \pm 0.07$ & $<\mathrm{DL}$ & $<\mathrm{DL}$ & 0.23 & $96 \%$ & $24 \%$ & $0.01 \pm 0.04$ & $<\mathrm{DL}$ & 0.01 & 0.14 & $80 \%$ & $7 \%$ \\
\hline & $\mathrm{PM}_{10}$ & $0.06 \pm 0.29$ & $<\mathrm{DL}$ & $<\mathrm{DL}$ & 0.27 & $91 \%$ & $27 \%$ & $0.02 \pm 0.03$ & $<\mathrm{DL}$ & 0.01 & 0.14 & $80 \%$ & $7 \%$ \\
\hline \multirow[t]{2}{*}{$-\mathrm{Mg}^{2+}$} & $\mathrm{PM}_{2.5}$ & $0.04 \pm 0.06$ & $<\mathrm{DL}$ & 0.03 & 0.19 & $96 \%$ & $51 \%$ & $0.05 \pm 0.07$ & $<\mathrm{DL}$ & 0.02 & 0.22 & $84 \%$ & $45 \%$ \\
\hline & $\mathrm{PM}_{10}$ & $0.05 \pm 0.10$ & $<\mathrm{DL}$ & 0.02 & 0.24 & $92 \%$ & $50 \%$ & $0.09 \pm 0.11$ & $<\mathrm{DL}$ & 0.06 & 0.35 & $84 \%$ & $57 \%$ \\
\hline \multirow[t]{2}{*}{$\mathrm{Ca}^{2+}$} & $\mathrm{PM}_{2.5}$ & $0.26 \pm 0.21$ & 0.07 & 0.22 & 0.65 & $96 \%$ & $96 \%$ & $0.18 \pm 0.24$ & 0.01 & 0.13 & 0.72 & $84 \%$ & $84 \%$ \\
\hline & $\mathrm{PM}_{10}$ & $0.30 \pm 0.26$ & 0.04 & 0.23 & 0.96 & $92 \%$ & $91 \%$ & $0.50 \pm 0.71$ & 0.01 & 0.26 & 2.42 & $83 \%$ & $83 \%$ \\
\hline
\end{tabular}

$<$ DL: the respective percentile was below the detection limit.

percentiles of the cumulative distribution of concentrations, and the fraction of time data are obtained for each ion or gas. When calculating the averages, data values below detection limit (DL) were taken into account by giving them the value of $0.5 \times \mathrm{DL}$. The concentrations of sulphate, nitrate, ammonium, and calcium were most of time higher than the detection limits. The lowest fraction of concentrations above detection limit in $\mathrm{PM}_{10}$ was for potassium.

The gas-phase concentrations presented below are in ppb and the aerosol concentrations in $\mu \mathrm{g} \mathrm{m}^{-3}$ at $20^{\circ} \mathrm{C}$ and 1013 mbar. The time of the measurements in the figures is the local winter time (UTC $+2 \mathrm{~h})$.

\subsection{Temporal variations of aerosol concentrations}

Several observations can be made already from the time series of the concentrations of the ions analyzed from the aerosol phase in both the $\mathrm{PM}_{2.5}$ and $\mathrm{PM}_{10}$ size ranges (Fig. 1). The data for which the MARGA software automatic fitting routine to the chromatograms does not yield any concentrations are given as a discontinuity in the graph. This is an effective detection limit. Some of the breaks in the time series are due to the fact that the instrument was not running because of some technical issue such as maintenance operations.
The MARGA software does not always recognize a small sodium peak next to a larger ammonium peak or vice versa, which leads to discontinuities in these data. For chloride there is an additional reason for the discontinuities: before the anion column gets exhausted, the chloride peak slowly disappears to the water dip in the beginning of the chromatogram.

The two size ranges measured with the MARGA followed each other well, especially for sulphate, ammonium and nitrate but worse for calcium and magnesium. This is reasonable as it is well known that the latter two exist both in soil dust and sea salt and that the size distributions of both of these aerosol types are dominated by coarse particles. The size fractions will be discussed more below.

The variation of the aerosol concentrations has two types: short peaks that are probably due to some local source in Helsinki, and slower, several-day-long variations that are due to long-range transport. The latter will be discussed below by using back trajectories. One interesting peak can be mentioned. The highest potassium concentrations were measured during the New Year Eve celebrations: $\mathrm{K}^{+}$concentrations rose above $1 \mu \mathrm{g} \mathrm{m}^{-3}$ at 19:00 p.m. on 31 December 2009, reached the peak $8.1 \mu^{-3} \mathrm{~g} \mathrm{~m}^{-3}$ at 21:00-22:00 and decreased again below $1 \mathrm{gg} \mathrm{m}^{-3}$ at 03:00 a.m. on 1 January 2010. In 


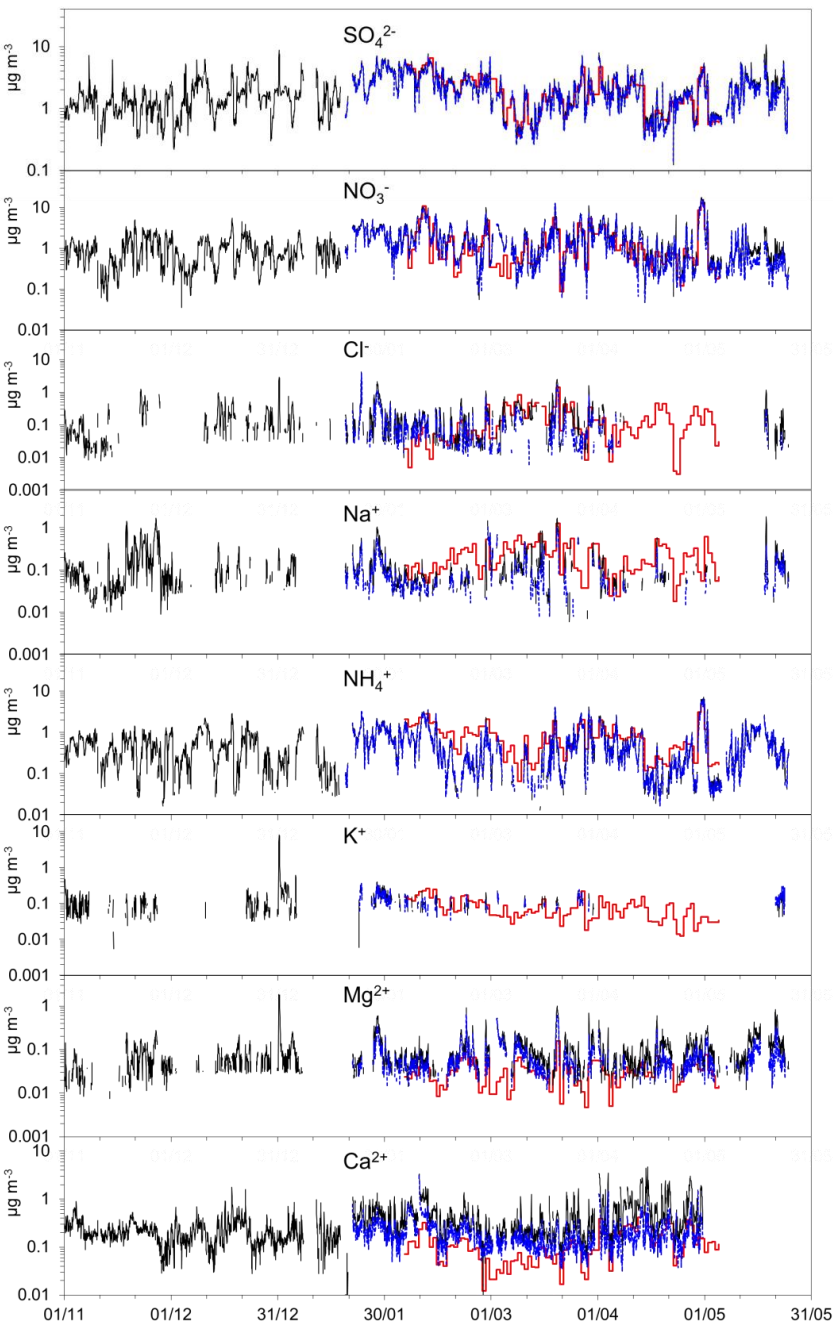

Fig. 1. Hourly-averaged concentrations of inorganic ions in aerosols at SMEAR III from 1 November 2009 to 25 May 2010. MARGA data in $\mathrm{PM}_{10}$ (black line) and $\mathrm{PM}_{2.5}$ (blue line); concentrations analyzed from 24-h PM 10 filter samples (red line). Note: before 19 January 2010 , there was only a total aerosol inlet in use and no $\mathrm{PM}_{2.5}$ cyclone.

this same fireworks-related peak, the concentrations of the other ions also increased clearly.

The sum of the analyzed ions follows well the temporal variation of the mass concentration calculated from the DMPS (Fig. 2). Here the mass concentration from the DMPS data was calculated assuming the density of $1.5 \mathrm{~g} \mathrm{~cm}^{-3}$ for spherical particles to generate an independent estimate for aerosol mass concentration. Figure 2 shows that the high and the low concentrations of the two methods occurred mainly simultaneously. However, the ion concentrations obviously explain only part of the mass: even if we compare $\mathrm{PM}_{1}$ from the DMPS and the sum of ions in $\mathrm{PM}_{10}$ from the MARGA, $\mathrm{PM}_{1}$ is $97 \%$ of time larger than the sum of the ions. This means that a large fraction of aerosol mass has not been ana-

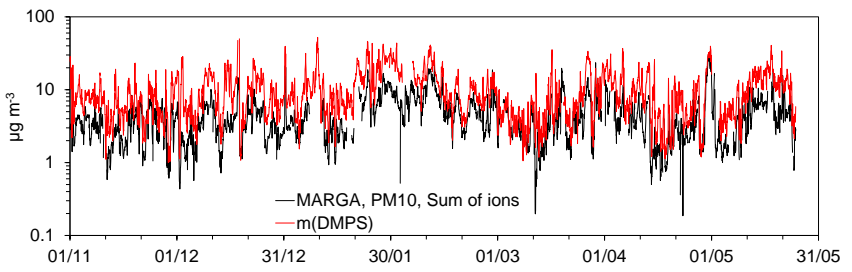

Fig. 2. Sum of inorganic ion concentrations in aerosols measured with MARGA in the size range $D_{\mathrm{p}}<10 \mu \mathrm{m}$ (noting that before 19 January 2010 there was only a total aerosol inlet in use) and the mass concentration of particles estimated from the particle number size distributions ( $m$ (DMPS)) in the size range $D_{\mathrm{p}}<1 \mu \mathrm{m}$ and assuming the density of $1.5 \mathrm{~g} \mathrm{~cm}^{-3}$.

lyzed. This is in line with earlier studies, for instance by Timonen et al. (2008) who observed that most of aerosol mass often consists of organics also in Helsinki.

\subsection{Comparisons of aerosol data with ions analyzed from filter samples}

The concentrations measured with the MARGA after the $\mathrm{PM}_{10}$ inlet was installed were compared with those analyzed from the Teflon filters by plotting them in the time series (Fig. 1) and by calculating linear regressions (Fig. 3). For the regressions the hourly MARGA data were first averaged over the sampling periods of the filters. Values below detection limit (DL) were taken into account by giving them the value of $0.5 \times$ DL. For the regressions, only those filter sampling periods were used, during which at least $50 \%$ of the MARGA data of the ion to be analyzed were $>$ DL, in order to reduce the weight of the more uncertain data. The reason is that for some ions there were several sampling periods during which there were no hourly data $>$ DL. The extreme example is $\mathrm{K}^{+}$that did not have any single filter sampling period during which all hourly data were $>\mathrm{DL}$, and there were only 5 sampling periods out of 88 during which at least $50 \%$ of the hourly data were $>$ DL (Table 3 ). If $\mathrm{K}^{+}$data from all the 88 filter sampling periods had been used for the regressions, most of the data points used for the fitting would have been given the same value, and $0.5 \times \mathrm{DL}$ and the regression would have been meaningless. On the other hand, if only those sampling periods had been taken into account during which concentrations during all $24 \mathrm{~h}$ had been $>\mathrm{DL}$, the amount of data points for the regression would have been reduced an unnecessary amount. For instance, the concentration of an ion may have been $<$ DL during two hours of some sampling period and it makes sense to replace these two values by $0.5 \times \mathrm{DL}$, calculate the sampling-period average, and use that value in the regression. The approach used now is a compromise between these two: using either all data even if most of them were $<\mathrm{DL}$ or not using any of the data where any hourly value was $<$ DL. 

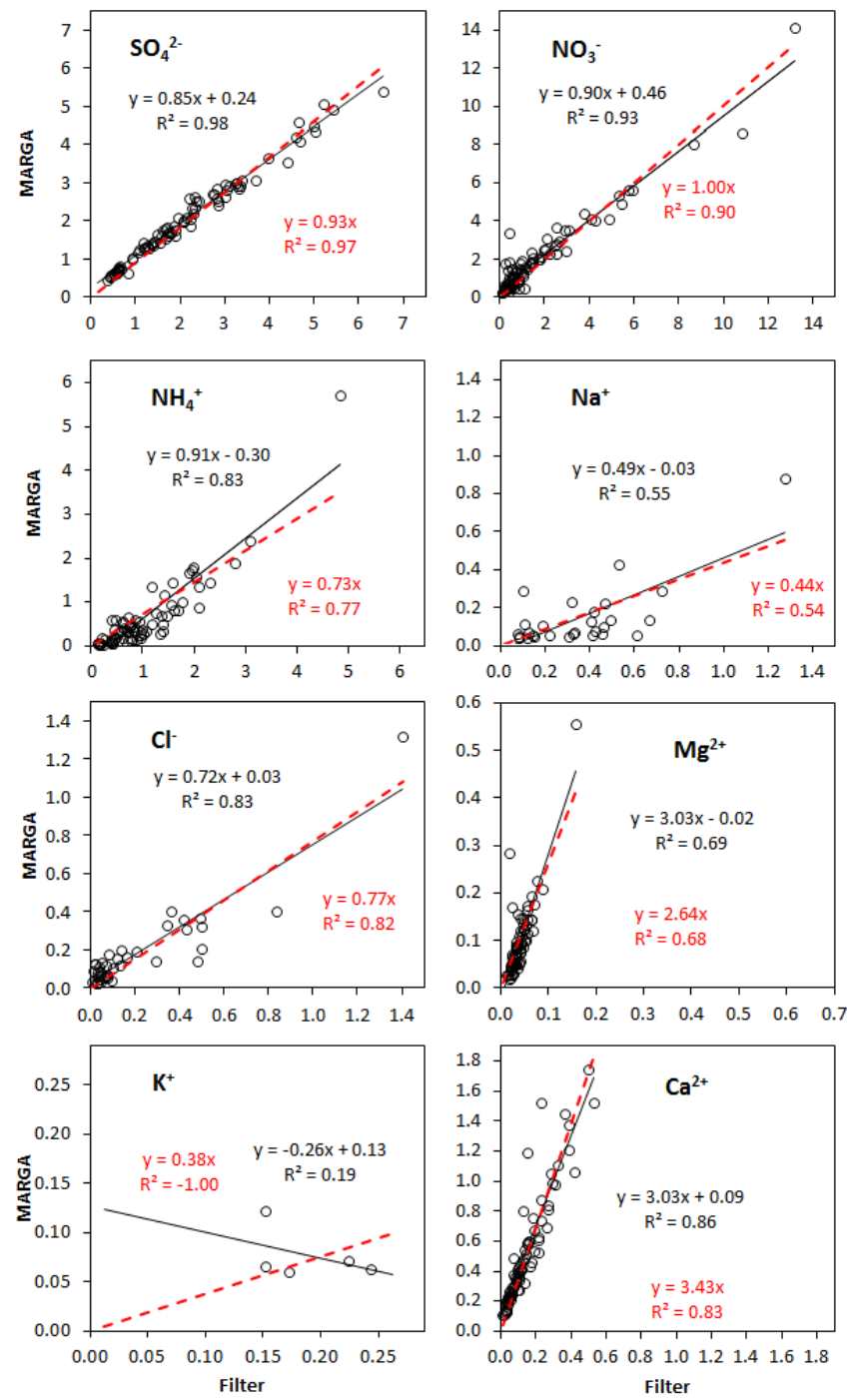

Fig. 3. Comparisons of concentrations of ions in the size range $D_{\mathrm{p}}<10 \mu \mathrm{m}$ measured with the MARGA and analyzed from Teflon filters. The MARGA data were averaged over the filter sampling periods. Unit: $\mu \mathrm{g} \mathrm{m}^{-3}$. The linear regressions with the black lines and equations were calculated by fitting both slopes and offsets and those with the red dashed lines and red equations by forcing the offset to zero.

The linear regressions were calculated both by fitting both slope and offset and by forcing the offset to zero. Regressions calculated by using the MS Excel 2010 linest function also yield the uncertainties of the slope and offset as standard errors (stderr). From these the respective standard deviations were calculated from stdev $=\sqrt{n}$. stderr, where $n$ is the number of observations. The slopes, offsets and their uncertainties are given in Table 3.

The slopes for sulphate, ammonium, and nitrate were all close to each other, ranging from 0.85 to 0.91 (Table 3, Fig. 3). From these comparisons alone it is not possible to determine whether the MARGA or the filter sampling re-
Table 3. Coefficients of the linear regressions of the concentrations measured with the MARGA data vs. those analyzed from the $\mathrm{PM}_{10}$ filters and the $\mathrm{SO}_{2}$ measured with a Horiba APSA 360 monitor: $C($ MARGA $)=k \cdot C($ comparison method $)+C_{0} \cdot N=$ number of observations used in the regression. For explanation of the uncertainties of $k$ and $C_{0}$ see Sect. 3.2. For $\mathrm{K}^{+}$the $r^{2}$ statistic is negative for the model without a constant, indicating that the model is not appropriate for the data.

\begin{tabular}{lcccc}
\hline & $N$ & $k \pm \operatorname{std}(k)$ & $C_{0} \pm \operatorname{std}\left(C_{0}\right)$ & $r^{2}$ \\
\hline $\mathrm{Cl}^{-}$ & 38 & $0.72 \pm 0.33$ & $0.03 \pm 0.11$ & 0.83 \\
& & $0.77 \pm 0.32$ & & 0.82 \\
$\mathrm{NO}_{3}^{-}$ & 84 & $0.90 \pm 0.24$ & $0.46 \pm 0.69$ & 0.93 \\
& & $1.00 \pm 0.23$ & & 0.90 \\
$\mathrm{SO}_{4}^{2-}$ & 87 & $0.85 \pm 0.12$ & $0.24 \pm 0.30$ & 0.98 \\
& & $0.93 \pm 0.08$ & & 0.97 \\
$\mathrm{Na}^{+}$ & 28 & $0.49 \pm 0.46$ & $-0.03 \pm 0.20$ & 0.55 \\
& & $0.44 \pm 0.27$ & & 0.54 \\
$\mathrm{NH}_{4}^{+}$ & 85 & $0.91 \pm 0.42$ & $-0.30 \pm 0.54$ & 0.83 \\
& & $0.73 \pm 0.30$ & & 0.77 \\
$\mathrm{~K}^{+}$ & 5 & $-0.26 \pm 0.70$ & $0.13 \pm 0.13$ & 0.19 \\
& & $0.38 \pm 0.19$ & & -1.0 \\
$\mathrm{Mg}^{2+}$ & 69 & $3.03 \pm 2.04$ & $-0.02 \pm 0.09$ & 0.69 \\
& & $2.64 \pm 0.98$ & & 0.68 \\
$\mathrm{Ca}^{2+}$ & 82 & $3.03 \pm 1.26$ & $0.09 \pm 0.23$ & 0.86 \\
& & $3.43 \pm 0.85$ & & 0.83 \\
$\mathrm{SO}_{2}$ & 3701 & $0.90 \pm 0.31$ & $-0.08 \pm 0.68$ & 0.89 \\
& & $0.88 \pm 0.23$ & & 0.89 \\
\hline
\end{tabular}

sults are closer to the true ones. However, the filter sampling method is routine and the laboratory follows strict EMEP protocols (EMEP, 2007) so this suggests that the concentrations given by the MARGA were underestimated. For ammonium it should also be noted that there is the possibility of a positive artifact in the filter samples. If there is ammonia in the laboratory air that reacts with sulphate in the filters and forms ammonium, the resulting ammonium concentrations will be higher than they were originally. Filters may also result in a negative artifact: ammonium nitrate is semivolatile and if the filters are stored at elevated temperatures, both ammonium and nitrate may volatilize from the filters. The filter handling was done at room temperature so this effect can be considered to be negligble.

The MARGA software does not always recognize small ammonium and sodium peaks which eluate next to each other. This leads to underestimation of both compounds and it is obviously more severe for sodium (Table 3, Fig. 3). For $\mathrm{Mg}^{2+}$ and $\mathrm{Ca}^{2+}$ the slopes were clearly above one, i.e., 3.0. It was discovered during the following campaign that all these were artifacts that could be significantly reduced by replacing the loop with a concentration column. It was thus shown that the reason for high $\mathrm{Mg}^{2+}$ and $\mathrm{Ca}^{2+}$ was either a dirty loop or sensitivity or the MARGA software could not calculate the small peak areas to concentrations correctly. The 


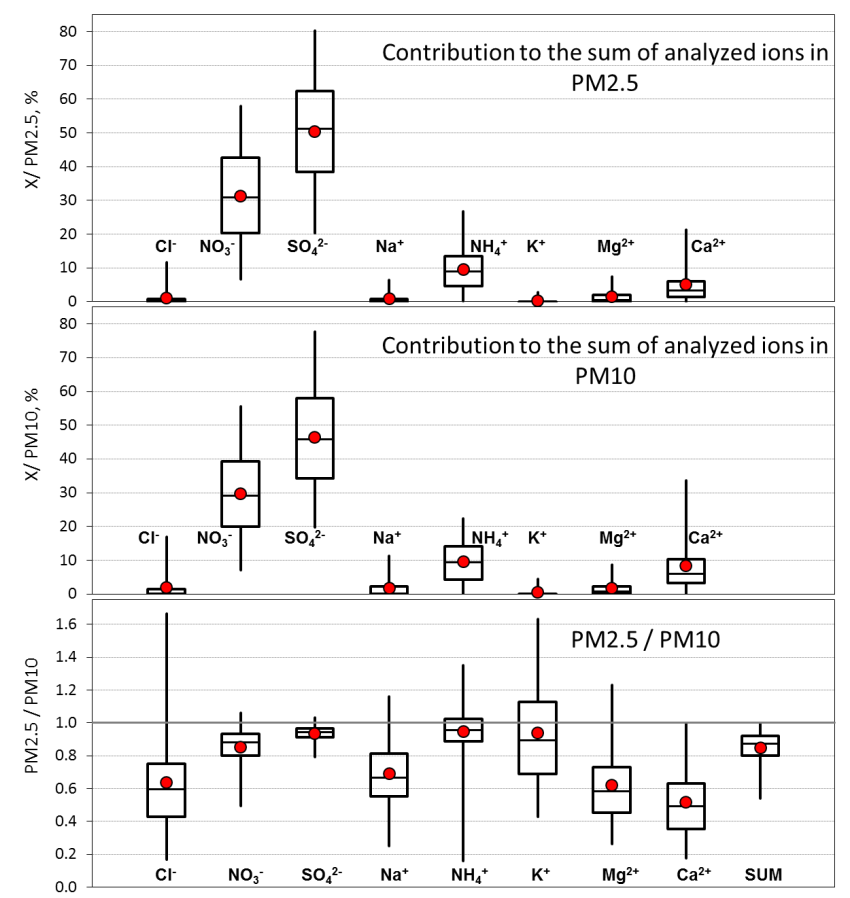

Fig. 4. Contributions of the major ions to their sum and the ratios of ion concentrations in two size ranges $\mathrm{PM}_{10}\left(D_{\mathrm{p}}<10 \mu \mathrm{m}\right)$ and $\mathrm{PM}_{2.5}\left(D_{\mathrm{p}}<2.5 \mu \mathrm{m}\right)$ in the period when both the $\mathrm{PM}_{10}$ inlet and the $\mathrm{PM}_{2.5}$ cyclone were in use. The box represents the 25 th to 75 th percentile range, the bars the 95 percent range (2.5th and 97.5th percentiles), the horizontal line the median and the red circle the averages of the hourly-averaged data.

results related to the concentration column will be presented in a forthcoming paper (Makkonen et al., 2012), however, and will not be discussed further in this paper.

Sulphate concentrations had the best correlation of MARGA vs. filters with $r^{2}=0.98$; the correlation was lower for the rest of the ions. There was no correlation for potassium $\left(r^{2}=0.19\right)$. The negative $r^{2}$ statistics for the $\mathrm{K}^{+}$regression indicates that the model with no offset is not appropriate for the data. Actually, for $\mathrm{K}^{+}$there are not enough data to get a statistically significant regression at all. This is clearly due to the fact that most of the $\mathrm{K}^{+}$concentrations were below the MARGA detection limit.

\subsection{Aerosol concentration in the two size ranges}

The MARGA aerosol data were used for estimating their contribution to the sum of the analyzed ions and for studying their size distribution in the time period when both the $\mathrm{PM}_{10}$ inlet and the $\mathrm{PM}_{2.5}$ cyclone were in use, from 19 January to 24 May 2010 (Fig. 4). The size distribution is of course just a crude estimation, since there were only two size ranges. At each hour the concentrations were summed up and the ratio of each ion to the sum was calculated. On average, sulphate is responsible for most (50.4\%) of inorganic ion mass after

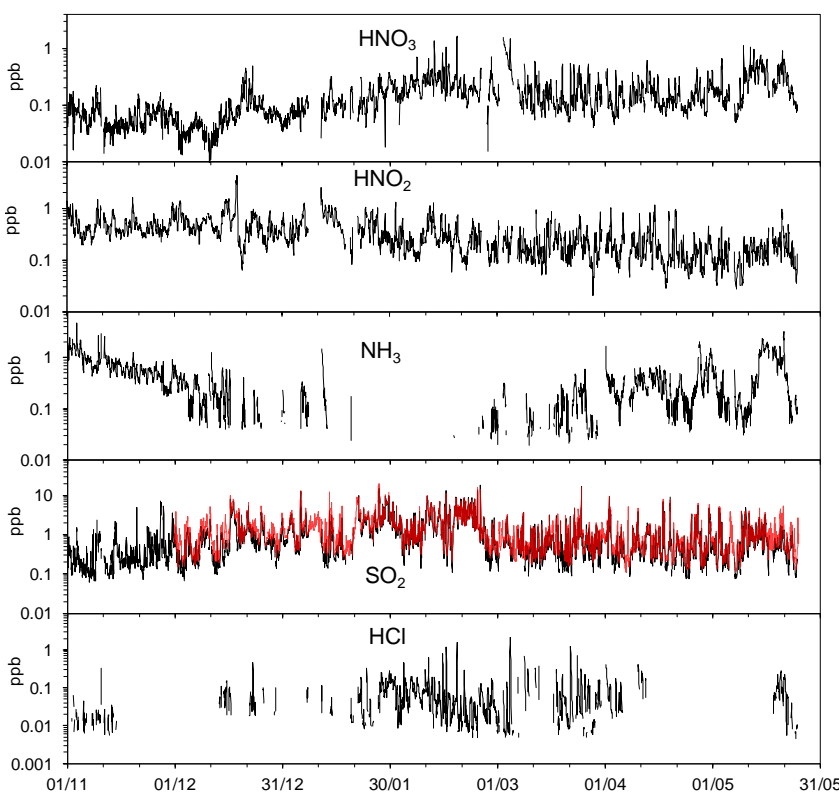

Fig. 5. Hourly-averaged concentrations of gases measured with the MARGA $\left(\mathrm{HNO}_{3}, \mathrm{HNO}_{2}, \mathrm{NH}_{3}\right.$, and $\left.\mathrm{SO}_{2}\right)$ at SMEAR III from 1 November 2009 to 25 May 2010. The red line in the $\mathrm{SO}_{2}$ time series is the data measured with a TEI 43iTL monitor.

the $\mathrm{PM}_{2.5}$ inlet and slightly less $(46.4 \%)$ after the $\mathrm{PM}_{10}$ inlet. There are cases when sulphate alone contributed more than $80 \%$ to the sum. Nitrate was the second most important ion, as far as aerosol mass is concerned, and there were cases when nitrate contributed more than $50 \%$ to the sum after both inlets.

The $\mathrm{PM}_{2.5}$-to-PM 10 ratio should never be larger than one. For the averages this is the case for all ions, but for ammonium and potassium, even the 75th percentile of cumulative distribution of the ratio is $>1$ (Fig. 4). These are cases when concentrations were very low, just above detection limits, and the uncertainties were high. Calcium, magnesium, sodium and chloride are major constituents of soil dust and sea salt. For them the $\mathrm{PM}_{2.5}$-to- $\mathrm{PM}_{10}$ ratio should be clearly $<1$ and this proves to be the case, most clearly for calcium. For the sum of all ions, $97.5 \%$ of the ratios were $<1$ so in general the size fractionation seems to work in a logical direction. However, more measurements on the large particles with different methods, for example an impactor with sharp cutoffs, should be done to find out the true large particle sampling efficiency of the MARGA.

\subsection{Temporal variation of the gases and their relationships}

The hourly-averaged concentrations of gases measured with the MARGA $\left(\mathrm{HNO}_{3}, \mathrm{HNO}_{2}, \mathrm{NH}_{3}\right.$, and $\left.\mathrm{SO}_{2}\right)$ are presented in Fig. 5. Of these gases, sulphur dioxide is the only one that was measured also with an independent method: a TEI 43iTL monitor. These two agreed well, as is seen in the time series 


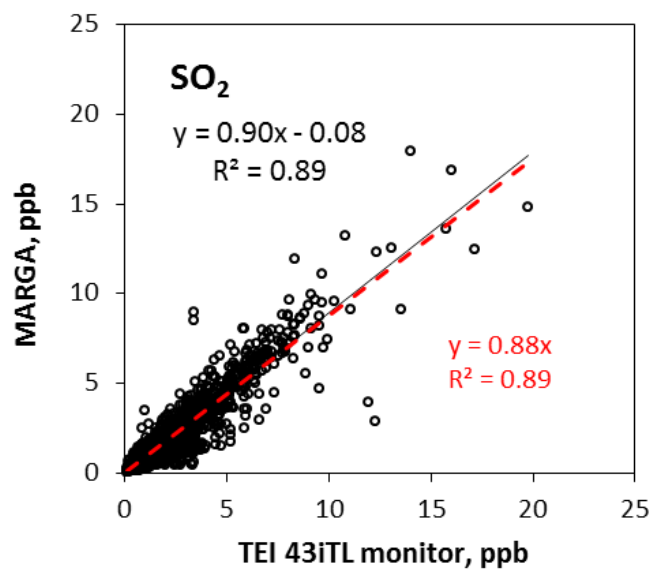

Fig. 6. Sulphur dioxide measured with the MARGA and a TEI 43iTL $\mathrm{SO}_{2}$ monitor, all hourly averages. The linear regression with the black line and equation was calculated by fitting both the slope and the offset and the regression with the red dashed line and red equation by forcing the offset to zero.

and in the scatter plot (Fig. 6). For the other gases, we can only compare our data with values measured in other sites just to see whether the values are in a reasonable range.

\subsection{1 $\mathrm{HNO}_{3}$ and $\mathrm{HNO}_{2}$}

To get some estimate of the general level of $\mathrm{HNO}_{3}$ concentrations, the data from the SMEAR II station in Hyytiälä in the southwestern part of central Finland were used for comparison. The average $\mathrm{HNO}_{3}$ concentration $(0.16 \mathrm{ppb})$ of the whole measurement period at SMEAR III was almost the same as the average $\mathrm{HNO}_{3}$ measured using a EMEP filter pack at SMEAR II $(0.15 \mathrm{ppb})$ in central Finland during the same period (unpublished data, analyzed at FMI/AQR). The yearly average concentration $0.05 \mathrm{ppb}$ measured with MARGA at the EMEP supersite in south-eastern Scotland in 2007 was much lower (Cape, 2009). So, in principle the order of magnitude of the $\mathrm{HNO}_{3}$ concentrations is reasonable. However, we cannot exclude losses in our inlet system and underestimation due to that. To evaluate inlet losses our present data are not sufficient.

A major pathway in the formation of $\mathrm{HNO}_{3}$ is the reaction $\mathrm{NO}_{2}+\mathrm{OH}^{*}+\mathrm{M} \rightarrow \mathrm{HNO}_{3}+\mathrm{M}$, where the hydroxyl radical $\mathrm{OH}^{*}$ is originated from photochemical reactions. Nitrous acid $\mathrm{HNO}_{2}$ formed in the reaction $\mathrm{NO}+\mathrm{OH} \cdot+\mathrm{M} \rightarrow \mathrm{HNO}_{2}+\mathrm{M}$, on the other hand, is dissociated by solar radiation: $\mathrm{HNO}_{2}+$ $h v \rightarrow \mathrm{OH}^{*}+\mathrm{NO}$. Ozone is produced in photochemical reactions in sunlight and it is also transported downward from ozone rich air from above during daytime when mixing is efficient. At night it is destroyed when it reacts rapidly with $\mathrm{NO}$ according to $\mathrm{NO}+\mathrm{O}_{3} \rightarrow \mathrm{NO}_{2}+\mathrm{O}_{2}$ and also due to dry deposition. In locations where NO source is large, ozone can be totally destroyed (Finlayson-Pitts and Pitts, 2000). In other words, when there is sunlight, the expected $\mathrm{HNO}_{3}$ and $\mathrm{O}_{3}$

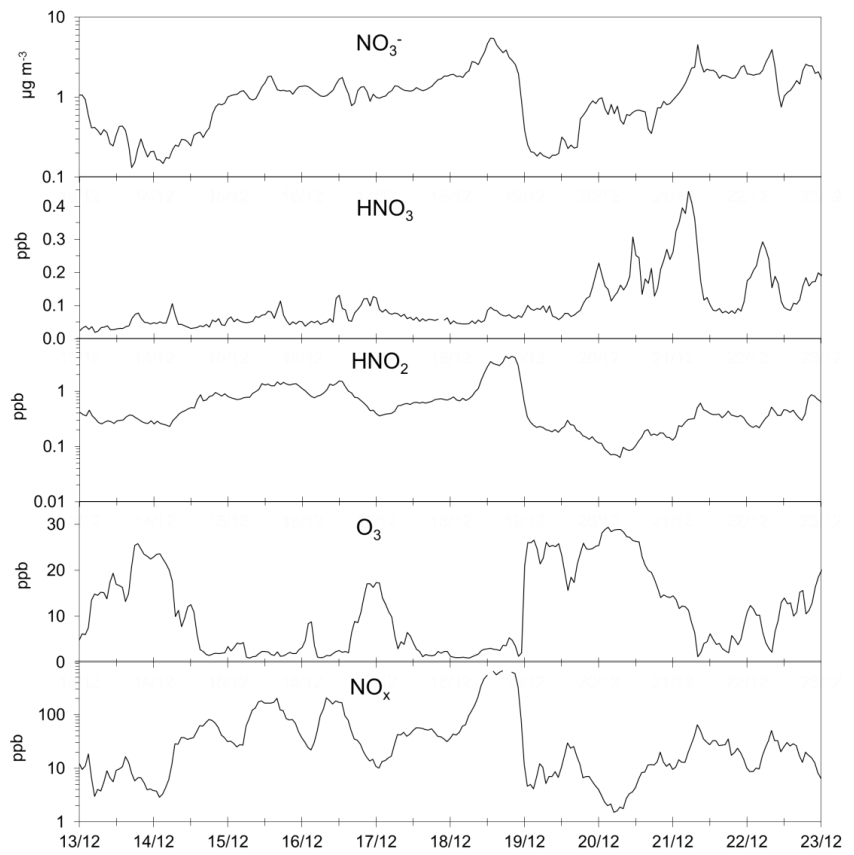

Fig. 7. Ozone, $\mathrm{NO}_{\mathrm{x}}$, and the nitrogen-containing gas-phase acids and nitrate in $\mathrm{PM}_{10}$ in the dark time of the year.

concentrations are higher and the HONO concentrations are lower than in the darkness. This is in agreement with our observations. Concentrations of the gases relevant to the above discussion are presented during a dark period in December (Fig. 7) and a light period in May (Fig. 8), when there is already a clear diurnal cycle. The concentration of nitrate does not follow the temporal variation of nitric acid, which suggests its sources are further away and it is transported over long distances. This is supported by the trajectory statistical analysis presented below in Sect. 3.6.

During the darkest months (November-January) when sunlight was very limited in the northern latitudes, the concentration of nitric acid was mostly below $0.1 \mathrm{ppb}$ and stayed stable throughout day and night. At the beginning of February when the amount of daylight increased and there was still snow cover on the ground, the variation of $\mathrm{HNO}_{3}$ increased and peaks up to 1-1.5 ppb were detected. In March and April the concentrations varied below $0.5 \mathrm{ppb}$. In May $\mathrm{HNO}_{3}$ concentration increased again and peaked up to $1 \mathrm{ppb}$. In the spring days there is enough light for the photochemical reactions to form $\mathrm{OH}$-radicals, which react with $\mathrm{NO}_{2}$ forming nitric acid. Also the snow cover affects the amount of radiation.

The diurnal cycle was calculated both for the winter and for the spring periods. Only the latter is shown in Fig. 9 because in winter there was no clear daily pattern. Also the diurnal cycle of nitrate in aerosol $\left(\mathrm{PM}_{10}\right)$ is shown because nitric acid is its precursor and because ammonium nitrate particles are semivolatile and may evaporate into ammonia 


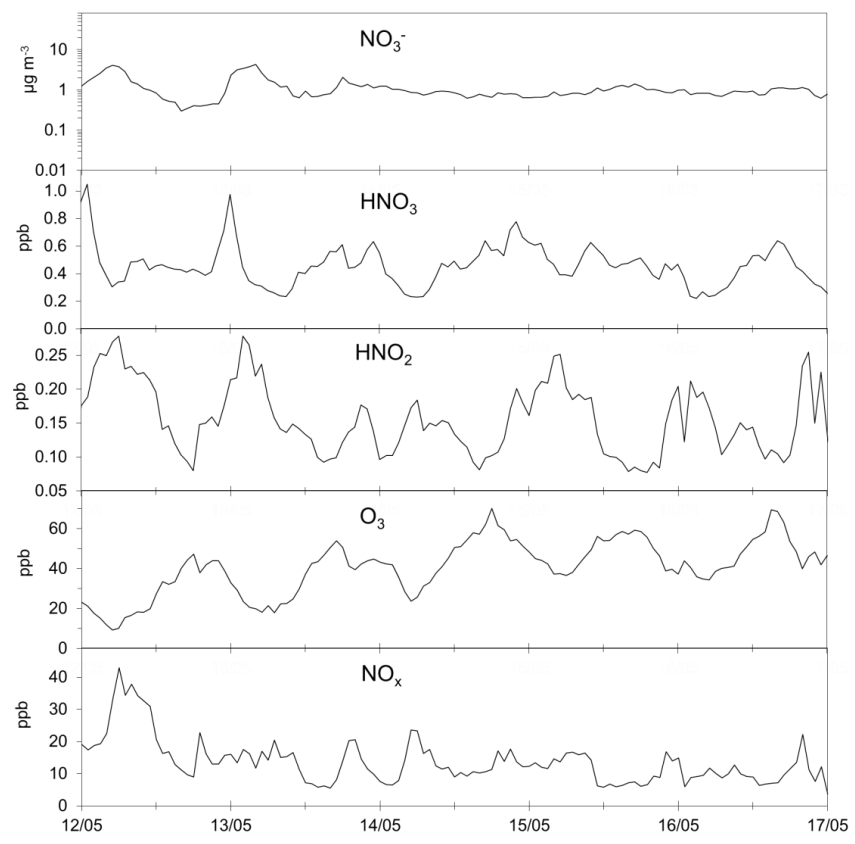

Fig. 8. Ozone, $\mathrm{NO}_{\mathrm{x}}$, and the nitrogen-containing gas-phase acids and nitrate in $\mathrm{PM}_{10}$ in late spring.

and nitric acid when temperature increases (e.g., Seinfeld and Pandis, 1998). Even though it was discussed above that the nitrate sources in general are far away from our measurement site, it did also have a diurnal cycle in spring, which can be observed from 3-month statistics. In MarchMay the $\mathrm{HNO}_{3}$ concentration had a minimum at 07:0009:00 and a clear maximum at 12:00-14:00 LT. Nitrate, on the other hand, had its maximum average concentration two hours earlier, at 10:00 (Fig. 9). These diurnal cycles resemble those observed at other sites, for instance Zürich (Fisseha et al., 2006), Pittsburgh (Wittig et al., 2004), and Oensingen, Switzerland (Wolff et al., 2010): the peak nitrate concentration is a few hours earlier than that of $\mathrm{HNO}_{3}$. The time lag can be explained by the temperature dependent partitioning of ammonium nitrate between the gas and aerosol phase (e.g., Fisseha et al., 2006). The times of the diurnal maxima are not quite the same at the sites. The reason is that the diurnal cycles depend both on the site and the time of the year. For example, in Oensingen in the late summer of 2006, the maximum $\mathrm{HNO}_{3}$ concentration was clearly later in the afternoon (16:00-17:00) (Wolff et al., 2010), which is about $4 \mathrm{~h}$ later than in our spring period in Helsinki. In our study the $\mathrm{HNO}_{3}$ concentration decreased in the afternoon, probably due to dry deposition and heterogeneous formation of nitrate, as suggested for example by Fisseha et al. (2006) for the similar cycle in Zürich. The day-to day variation of $\mathrm{HNO}_{3}$ was large in our data, which is due to variation in both sources and removal. $\mathrm{HNO}_{3}$ is typically removed both by dry deposition and by below-cloud scavenging. Precipitation data have not been used for the analysis to explain the variation.

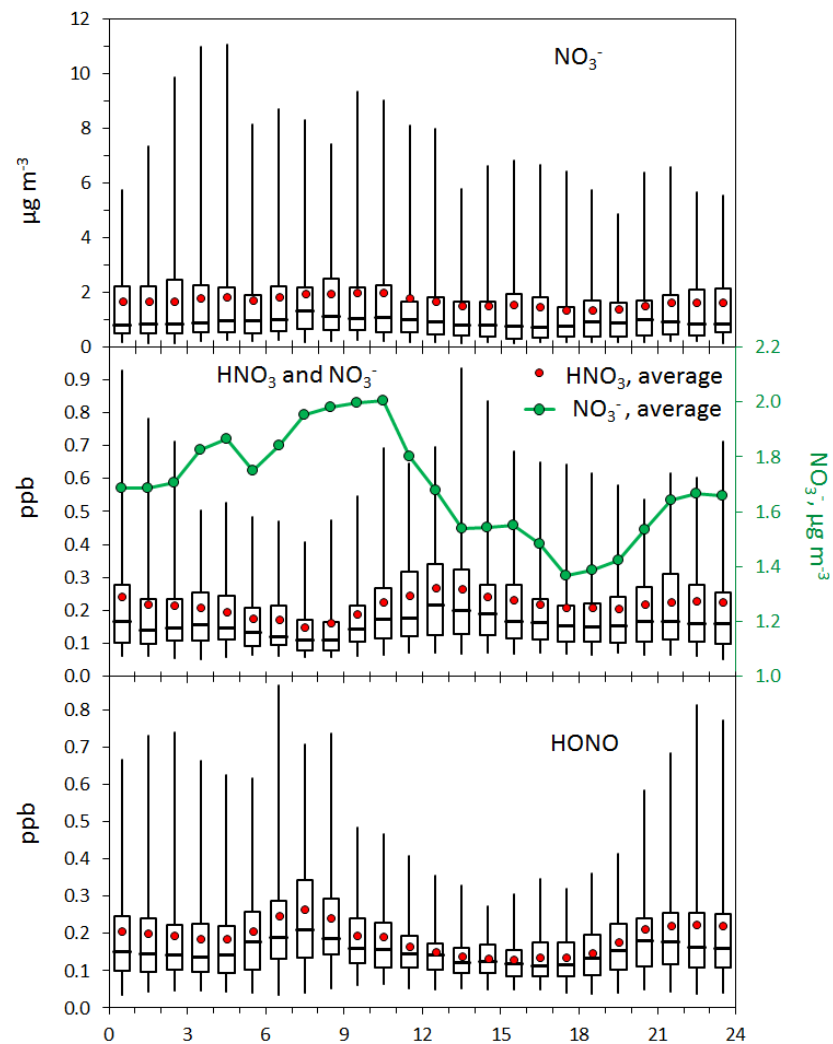

Fig. 9. Diurnal cycle of nitrate in $\mathrm{PM}_{10}$, nitric and nitrous acids in March-May 2010. The box represents the 25th to 75th percentile range, the bars the 95 percent range (2.5th and 97.5th percentiles), the horizontal line the median and the red circle the averages of the hourly-averaged data of each hour. Note: the average nitrate diurnal cycle is presented also in the middle panel with a different scale than in the upper panel, in order to highlight the variation.

Contrary to nitric acid, the HONO amount in air was higher in winter and decreased in spring. The highest concentrations were measured in December and January. The maximum (4.3 ppb) was measured on 18 December. From the middle of February, HONO concentrations varied below $1 \mathrm{ppb}$. Between 21 April and 18 May, HONO concentration was at the lowest, staying below $0.3 \mathrm{ppb}$. In winter HONO was higher in the daytime and lower at night, having a minimum at 04:00-05:00 LT. In spring concentrations rose in the early mornings, reaching maximum at 07:00-08:00, and decreased in the afternoons (minimum at 13:00-16:00, Fig. 9). This again resembles the cycle in Zürich, Switzerland, where HONO reached maximum at about 09:00 and decreased during the day until it reached minimum at 17:00 in March 2003 (Fisseha et al., 2006).

The amount of HONO in air depends on the $\mathrm{NO}_{\mathrm{x}}$ concentration. About half of the $\mathrm{NO}_{\mathrm{x}}$ emitted from the Earth's surface annually arises from fossil fuel combustion and the remainder from biomass burning and emissions from soil (Mosier, 2001). There are indications that HONO may be 

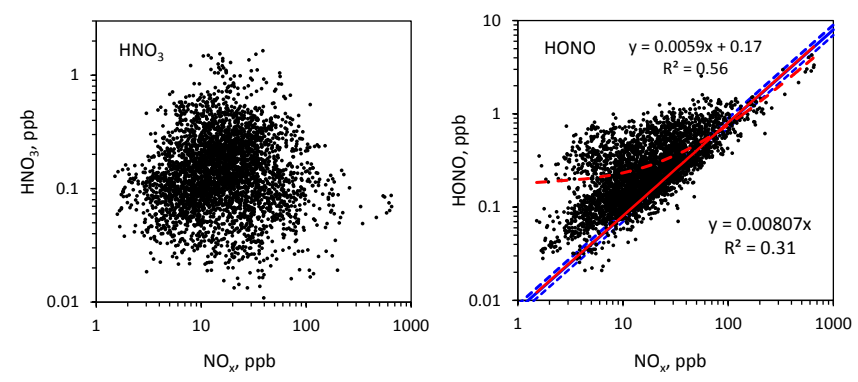

Fig. 10. Nitric and nitrous acid as a function of $\mathrm{NO}_{\mathrm{x}}$. The blue lines in the right panel are the $\mathrm{HONO}$-to- $\mathrm{NO}_{\mathrm{x}}$ ratios $0.008 \pm 0.001$ by Kurtenbach et al. (2001), the red continuous line the regression line that was done by forcing the offset to zero and the red dashed line without forcing the offset.

formed heterogeneously from $\mathrm{NO}_{2}$ on ground or airborne surfaces, for instance aerosol particles, especially soot, or cloud droplets (e.g., Gutzwiller et al., 2002). Positive correlations between $\mathrm{NO}_{\mathrm{x}}$ and $\mathrm{HONO}$ have been found. Kurtenbach et al. (2001) made extensive investigations of emissions and heterogeneous formation of HONO in a road traffic tunnel and found that the mean $\mathrm{HONO}-$ to- $\mathrm{NO}_{\mathrm{x}}$ ratio was $0.008 \pm 0.001$. We have plotted this ratio and the lower and higher values 0.007 and 0.009 as blue lines together with our data (Fig. 10). It is interesting that when a regression line was fit through the data by forcing the offset to zero, the slope is the same as was observed by Kurtenbach et al. (2001), suggesting that also at our site traffic is a major source of HONO. There are not many data points below the line. This means that most of the time there was at least as much HONO as the Kurtenbach et al. (2001) HONO-to- $\mathrm{NO}_{\mathrm{x}}$ ratio predicts. On the other hand, a large amount of the data points are clearly above the line, even by an order of magnitude. This suggests that traffic is not the only source of HONO at our site.

\subsubsection{Ammonia}

As the major base in the atmosphere, ammonia plays a key role for the neutralization of acidic gases and the formation of particulate matter (Asman et al., 1998; Kirkby et al., 2011). Furthermore, the effects of ammonia deposition can lead to eutrophication and acidification of soils (Ferm, 1998; Erisman et al., 2001; Butterbach-Bahl et al., 2011). The main sources of ammonia $\left(\mathrm{NH}_{3}\right)$ are animal waste, ammonification of humus followed by emission from soils, losses of ammonium-containing fertilizers from soils, industrial emissions, oceans, biomass burning and crops (Asman et al., 1998; Seinfeld and Pandis, 1998). About 50 to $75 \%$ of $\mathrm{NH}_{3}$ from terrestrial systems is emitted from animal and cropbased agriculture, from animal excreta and synthetic fertilizer application (Mosier, 2001). In winter when land is covered by snow and the sea is frozen, it may be expected that the ammonia concentrations are low. The agriculture-related and soil-related sources are strongest in summer, which as such already leads to a seasonal cycle.

We observed a seasonal cycle that is consistent with the above. Most $\mathrm{NH}_{3}$ concentrations were below detection limit in January and February. After that concentrations rose slightly, and as expected, highest peaks (1-3 ppb) were detected later in spring in April and May. Usually ammonia concentrations increase in May when the agricultural activities start (Ruoho-Airola et al., 2010).

The additional explanation for the seasonal cycle of ammonia is related to temperature in another way: at warm temperatures at daytime, ammonium nitrate particles may volatilize, and at cold temperatures the other way round, so the reaction $\mathrm{NH}_{3}+\mathrm{HNO}_{3}(\mathrm{~g}) \leftrightarrow \mathrm{NH}_{4} \mathrm{NO}_{3}$ (s) has a temperature-dependent balance. These are also in agreement with our observations: the concentrations of ammonium and nitrate were the highest in winter.

\subsection{3 $\mathrm{SO}_{2}$}

The anthropogenic sources of $\mathrm{SO}_{2}$ are primarily the combustion of sulphur-containing fossil fuels in power and heating plants, as well as industry and traffic, especially ships (e.g., Corbett et al., 1999, 2010; Stern, 2005; Vestreng et al., 2007). There are reasons to expect a seasonal cycle in $\mathrm{SO}_{2}$ concentrations: for instance heating plants operate at a higher power in winter, and in winter there is less light and thus lower concentrations of hydroxyl radical that oxidises $\mathrm{SO}_{2}$ (e.g., Seinfeld and Pandis, 1998). There was some seasonality in the $\mathrm{SO}_{2}$ concentrations, with higher concentrations in winter in January-February. The highest peak (18 ppb) was measured on 20 February. There was also some diurnal cycle in the $\mathrm{SO}_{2}$ concentration. In winter (November-February) they were not so clear: the average \pm standard deviation (median) $\mathrm{SO}_{2}$ concentrations were $1.6 \pm 2.1 \mathrm{ppb}(0.75 \mathrm{ppb})$ at noon and $1.2 \pm 1.4 \mathrm{ppb}(0.66)$ at midnight. In spring (March-May) they were clearer: the respective concentrations were $1.3 \pm$ $2.2 \mathrm{ppb}(0.62 \mathrm{ppb})$ at noon, and $0.56 \pm 0.50 \mathrm{ppb}(0.37 \mathrm{ppb})$ at midnight. The most plausible explanation for this cycle is that in daytime the emissions from ships at the harbors of Helsinki are stronger than at night, and ships are well-known sources of $\mathrm{SO}_{2}$ (e.g., Corbett et al., 1999, 2010). This interpretation was supported by calculating $\mathrm{SO}_{2}$ diurnal cycles using data measured at an air quality measurement station at the harbor of Helsinki. There the cycle was clearer and the concentrations higher (P. Anttila, senior scientist at FMI, personal communication, 2012). A further analysis of the $\mathrm{SO}_{2}$ concentration is out of the scope of the present paper.

\subsubsection{HCl}

The hydrochloric acid $(\mathrm{HCl})$ data is the most discontinuous of the gases. Its concentrations were above the detection limit most of February and March, and the rest of the time they were mainly below it. The highest peaks, up to $0.5-2 \mathrm{ppb}$, 


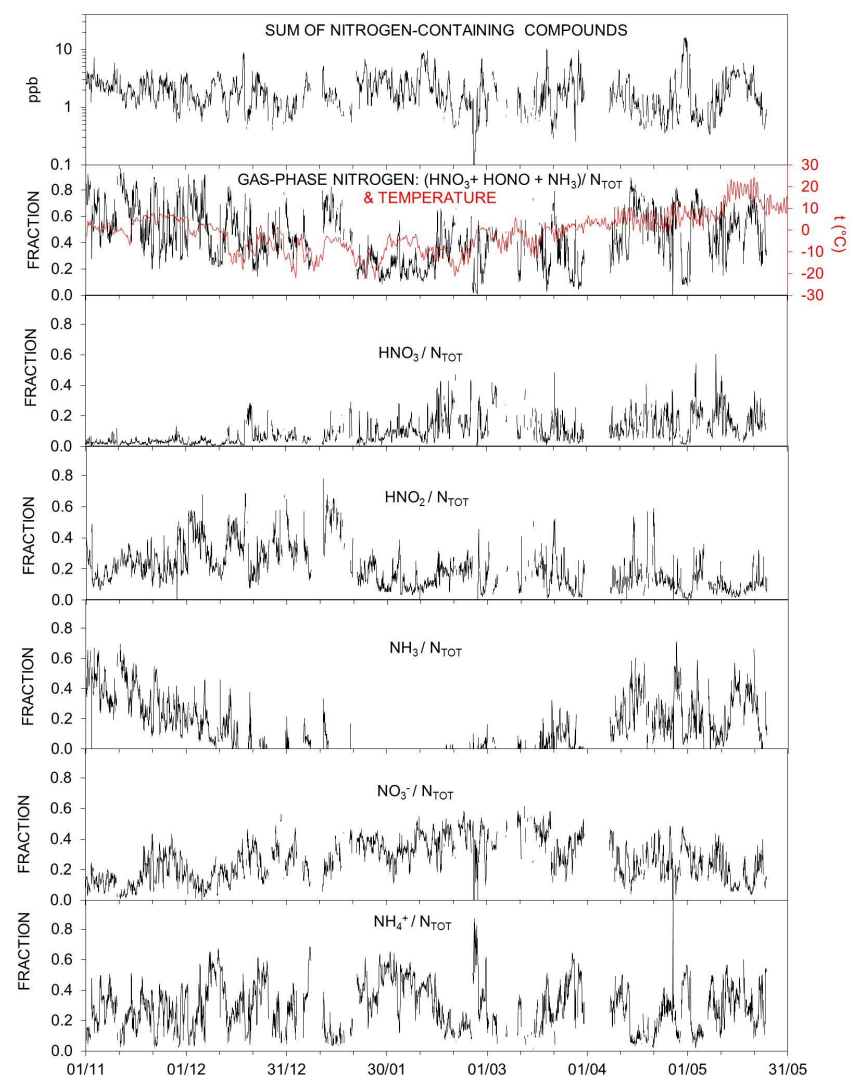

Fig. 11. Nitrogen fractionation into aerosol and gas phases. Upper panel: Sum of nitrogen-containing gases measurable with the MARGA $\left(\mathrm{HNO}_{3}+\mathrm{HNO}_{2}+\mathrm{NH}_{3}\right)$ and aerosols in $\mathrm{PM}_{10}$ $\left(\mathrm{NO}_{3}^{-}+\mathrm{NH}_{4}^{+}\right)$all in $\mathrm{ppb}$. The panels below that: fractions of nitrogen-containing compounds of the sum of all of them.

were measured in February and March. $\mathrm{HCl}$ stayed close to its detection limit in November-January. In spring it had a maximum at noon. $\mathrm{HCl}$ may be formed when some acid, for instance sulphuric or nitric acid, replaces chloride from seasalt aerosols. Anthropogenic sources include coal combustion, biomass burning, and waste incineration (Knipping and Dabdub, 2003). Now in our data the highest concentrations were observed in February and March when the Baltic Sea is still frozen. This suggests that the source is not sea salt.

\subsection{Nitrogen in gas and aerosol phases}

The fractionation of nitrogen into gas (excluding $\mathrm{NO}_{\mathrm{x}}$ ) and aerosol phases was studied by converting the concentrations into ppb units, adding them up $N_{\text {tot }}=\mathrm{NO}_{3}^{-}+$ $\mathrm{NH}_{4}^{+}+\mathrm{HNO}_{3}+\mathrm{HONO}+\mathrm{NH}_{3}$, and calculating the contribution of each of them to $N_{\text {tot }}$ (Fig. 11). The variation is large but one observation can be made: in the coldest months (January and February), most nitrogen is in the aerosol phase, and the balance turns to the gas phase when temperature increases. The median and the 95 percent range (2.5th to 97.5th percentiles) of the contribution of gas-phase nitro-

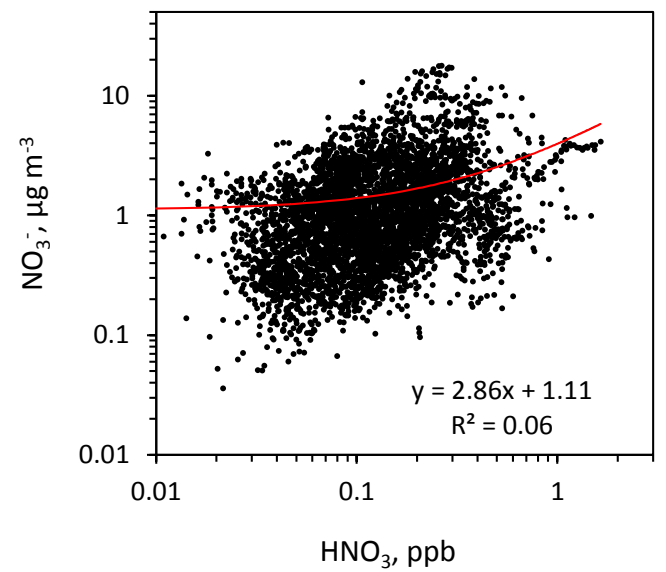

Fig. 12. Relationship of nitrate and nitric acid.

gen $f\left(N_{\text {gas }}\right)=\left(\mathrm{HNO}_{3}+\mathrm{HONO}+\mathrm{NH}_{3}\right) / N_{\text {tot }}$ was $28 \%(9-$ $70 \%)$ in January-February, and $53 \%(11-81 \%)$ in AprilMay. This is a general trend but large variations from this are also obvious in the time series. It can be observed that the contribution of nitrate is largest in March, which is not in any of the extremes either for temperature or solar radiation. No good explanation could be given.

Nitrate is formed when nitric acid gets into the aerosol phase. The scatter plot of nitric acid vs. nitrate (Fig. 12) shows that these species do not correlate well, which can be seen also for winter and summer in Figs. 7 and 8, respectively. A probable explanation is that the nitrate observed is more from long-range transport whereas the nitric acid is more from local sources. Also, the temperature-dependent fractionation into gas and aerosol phases affects the relationship.

\subsection{Aerosol acidity and source area analysis}

The aerosol data were next used for studies on the acidity of aerosols. The major acidifying and long-range transported aerosol components are sulphate, ammonium and nitrate. The ion equivalent sum of anions was calculated from

$\mathrm{SO}_{4(\mathrm{ekv})}^{2-}+\mathrm{NO}_{3(\mathrm{ekv})}^{-}+\mathrm{Cl}_{\mathrm{ekv}}^{-}=\frac{m\left(\mathrm{SO}_{4}\right)}{48}+\frac{m\left(\mathrm{NO}_{3}\right)}{62}+\frac{m(\mathrm{Cl})}{35.5}$

and that of the cations from

$$
\begin{aligned}
& \mathrm{NH}_{4(\mathrm{ekv})}^{+}+\mathrm{Na}_{(\mathrm{ekv})}^{+}+\mathrm{K}_{\mathrm{ekv}}^{+}+\mathrm{Ca}_{\text {ekv }}^{2+}+\mathrm{Mg}_{\text {ekv }}^{2+} \\
& \quad=\frac{m\left(\mathrm{NH}_{4}\right)}{18}+\frac{m(\mathrm{Na})}{23}+\frac{m(\mathrm{~K})}{39}+\frac{m(\mathrm{Ca})}{20}+\frac{m(\mathrm{Mg})}{12.5}
\end{aligned}
$$

where $\mathrm{m}$ stands for mass concentration. The ratio of these is $<1$ for acidic aerosols and $>1$ for basic. This calculation was done for the $\mathrm{PM}_{10}$ particles. The ratio was calculated with and without taking calcium into account because we wanted to see the effect of soil dust. In winter the aerosol is mainly acidic but in March and April basic (Fig. 13, top panel). It is 


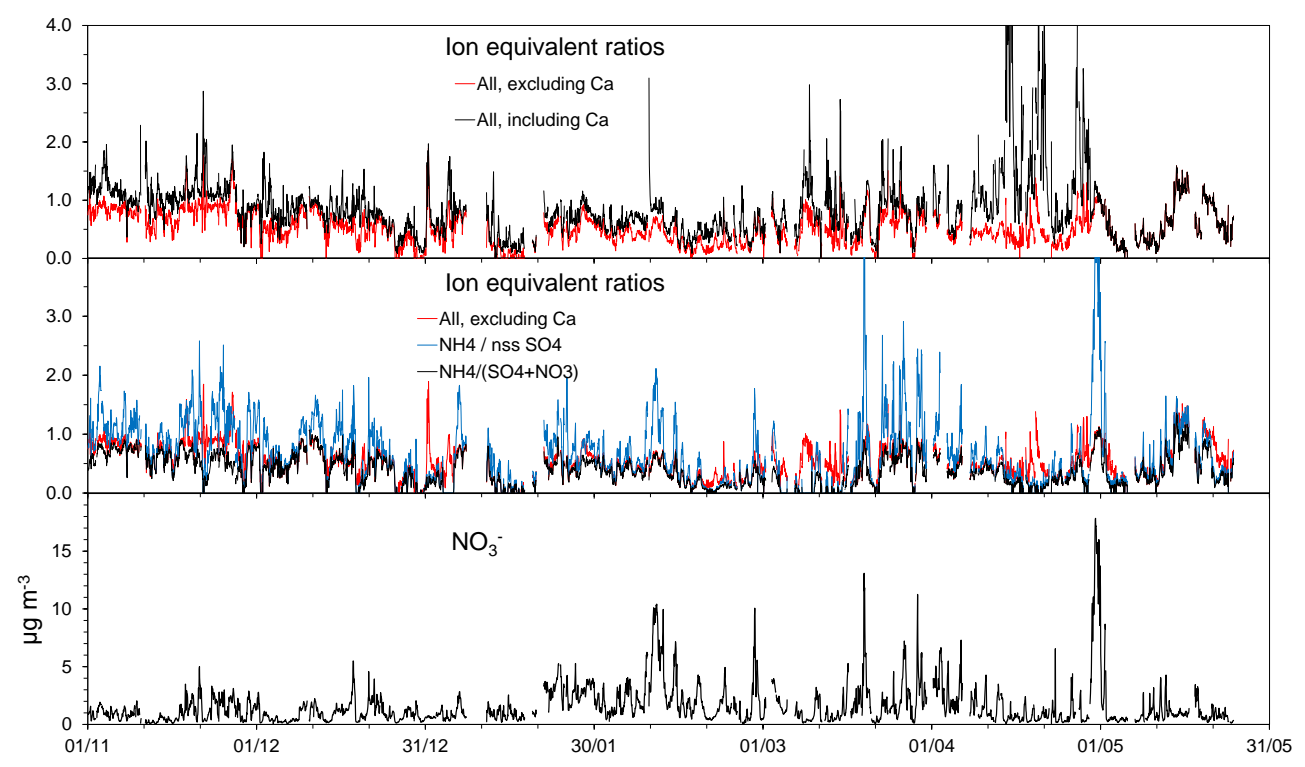

Fig. 13. Studies on the acidity of aerosols in $\mathrm{PM}_{10}$. Upper panel: ratio of sums of ion equivalent concentrations of cations to that of anions, including and excluding $\mathrm{Ca}^{2+}$ concentrations; middle panel: ratio of sums of ion equivalent concentrations of cations to that of anions excluding $\mathrm{Ca}^{2+}$ concentrations, the ratio of ammonium to non-seasalt sulphate ion equivalent concentrations, and the ratio of ammonium to the sum of non-seasalt sulphate and nitrate ion equivalent concentrations; lower panel: nitrate concentrations.

an indication of the well-known urban air quality problem in all Finnish cities in spring: road dust that is brushed from the roads during the spring road cleaning.

On the other hand, if the cation-to-anion ratio is calculated using only ammonium, non-sea salt sulphate (nss $\mathrm{SO}_{4}^{2-}=\mathrm{SO}_{4}^{2-}-0.25 \cdot \mathrm{Na}^{+}$, where 0.25 is the sulphate-tosodium ratio in sea water from the average sea salt composition in Seinfeld and Pandis, 1998), and nitrate, the ratio is essentially the same as when using all of the ions (Fig. 13, middle panel), whereas when only ammonium and nss sulphate is used, the ratio is often much higher than one. This means that there is more ammonium than is needed for neutralizing sulphuric acid into ammonium sulphate. Then the rest of ammonium is neutralizing nitrid acid into ammonium nitrate. However, there are long periods when the ratio is $<1$. To study the origin of the acidic aerosol, the concentration data were combined with back trajectories.

HYSPLIT4 (HYbrid Single-Particle Lagrangian Integrated Trajectory) trajectories (Draxler and Hess, 1998; Heinzerling, 2004; HYSPLIT-web) were calculated for an arrival height of $100 \mathrm{~m}$ with hourly interval, $96 \mathrm{~h}$ back in time. The trajectory data were used in a statistical way, presented earlier by Vakkari et al. (2011). At each time step the measured value of the chosen parameter was assigned to the grid cells $\left(0.5 \times 0.5^{\circ}\right)$ along the corresponding back trajectory so that the arrival time of the trajectory was equal to the measurement time. The geometric mean of values accumulated to each grid cell was calculated. The end result is a concentration field that suggests for each cell passed by air masses on the way to the measurement site, whether it contributed to relatively high or low values monitored at the receptor site. In order to ensure the statistical significance of the result, the geometric mean was calculated only if a minimum number of trajectories, set to 10 in this work, crossed a grid cell.

The analysis was done for nss sulphate, ammonium and nitrate. It shows clearly that these ions come from continental Europe (Fig. 14). When it was done for cation-to-anion ratios that were calculated using all ions, the result is far from clear (Fig. 15). This is because calcium comes with soil dust from near-by sources. But when the calculation is done using only ammonium, sulphate, and nitrate, the difference between continental and marine air from the Norwegian Sea becomes obvious: the continental aerosol is neutralized and the marine aerosol not.

\section{Summary and conclusions}

The first deployment of a MARGA instrument in Finland was presented here. Its performance was analyzed by comparing it with independent methods and the data were used to demonstrate some of the possibilities it gives for atmospheric chemistry studies.

The concentrations measured by the MARGA were mainly lower than those measured with standard Teflon filters. Linear regression yielded the following MARGA vs. filter slopes: 0.72 for $\mathrm{Cl}^{-}, 0.90$ for $\mathrm{NO}_{3}^{-}, 0.85$ for $\mathrm{SO}_{4}^{2-}, 0.91$ for $\mathrm{NH}_{4}^{+}, 0.49$ for $\mathrm{Na}^{+}, 3.0$ for $\mathrm{Mg}^{2+}$, and 3.0 for $\mathrm{Ca}^{2+}$ and 0.90 for the MARGA vs. $\mathrm{SO}_{2}$ monitor. For $\mathrm{K}^{+}$there were not enough data points to calculate a statistically significant linear regression. One of the goals with online measurements 

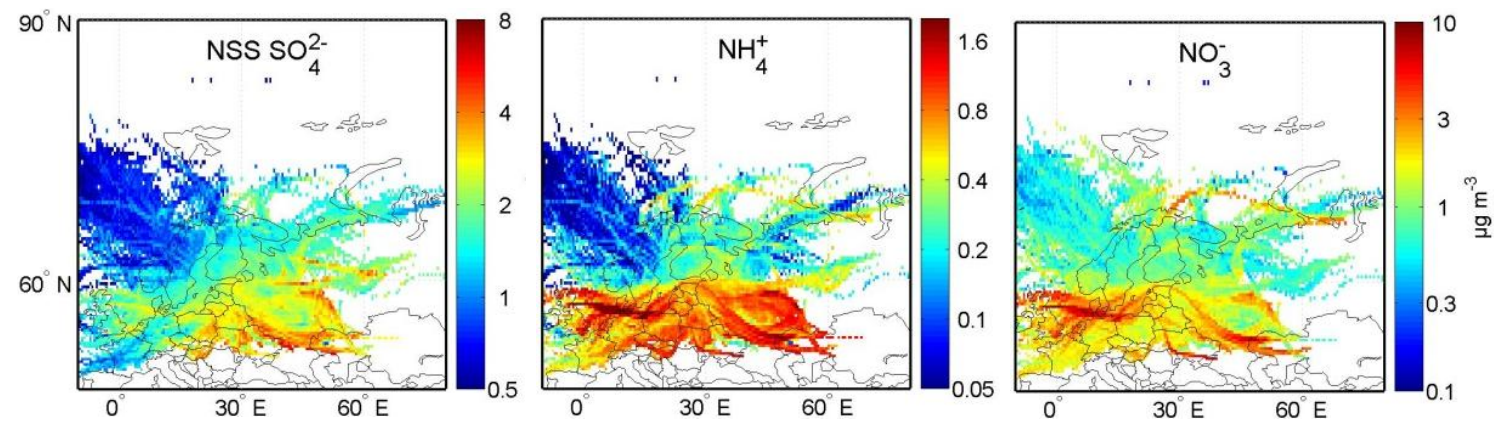

Fig. 14. Source areas of the most important secondary aerosol ion compounds as determined from trajectory statistics.
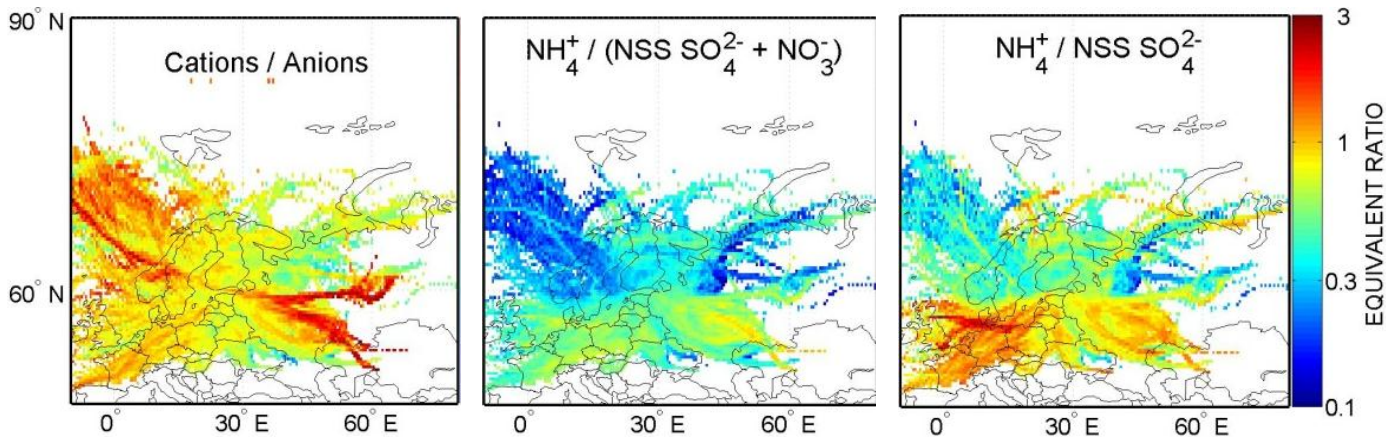

Fig. 15. Trajectory statistics of the ion equivalent ratios presented in Fig. 13.

is to use them to replace filter sampling within the EMEP network. From the results of this study this cannot be recommended, at least with the MARGA setup used during the period presented here. However, part of the discrepancies were later in a following campaign proven out to be solvable by using a concentration column for the cations. This needs to be studied rigorously.

However, the method is promising and it gives very valuable information on both gas and aerosol phases at time resolutions high enough for process studies. For instance, in spring we observed clear diurnal cycles of nitric and nitrous acids that could not have been observed with some impregnated filter method.

There were clear seasonal cycles of the nitrogen containing gases: the median concentrations of $\mathrm{HNO}_{3}, \mathrm{HONO}$, and $\mathrm{NH}_{3}$ were $0.09 \mathrm{ppb}, 0.37 \mathrm{ppb}$, and $0.01 \mathrm{ppb}$ in winter, respectively; and $0.15,0.15$, and 0.14 in spring, respectively. The $\mathrm{HNO}_{3}$ and HONO seasonal cycles were driven by the amount of solar radiation: when there was sunlight, the $\mathrm{HNO}_{3}$ concentrations were higher and the HONO concentrations were lower than in darkness. This was also the case with the diurnal cycles of the same gases in spring. Comparison with published $\mathrm{HONO}$-to- $\mathrm{NO}_{\mathrm{x}}$ ratios from a road traffic tunnel suggests that at our site traffic is a major source of HONO. On the other hand, a large amount of the HONO-to$\mathrm{NO}_{\mathrm{x}}$ ratios were clearly larger than these, even by an order of magnitude. This shows that traffic is not the only source of HONO at our site.

The seasonal cycle of ammonia was such that in the coldest months the concentrations were mainly below the detection limit and they increased with increasing temperature. This can be explained by agriculture-related and soil-related sources that are low when land is frozen and covered with snow.

The fractionation of nitrogen into gas and aerosol phases was studied by converting all concentrations into ppb units, summing then up and calculating the contribution of each of them to the sum. The gas-phase fraction of nitrogen decreased roughly with decreasing temperature, so that in the coldest period from January to February the median contribution was $28 \%$ but in April to May $53 \%$. However, in all months there were large fractionation variations that temperature alone cannot explain.

The analysis of ion balances showed that in winter aerosol is mainly acidic. In spring it gets basic due to soil dust. The trajectory statistics shows that even though the measurement site is in Helsinki and in the middle of the most densely populated parts of Finland, clear differences can be seen in the degree of neutralization as a function of source area. The longrange transported aerosol is acidic when it comes from the northern sectors and neutralized by ammonia when it comes from Central and Eastern Europe. 
Acknowledgements. This work was supported by the Academy of Finland as part or the Centre of Excellence program (project no 1118615).

Edited by: N. Mihalopoulos

\section{References}

Aan de Brugh, J. M. J., Henzing, J. S., Schaap, M., Morgan, W. T., van Heerwaarden, C. C., Weijers, E. P., Coe, H., and Krol, M. C.: Modelling the partitioning of ammonium nitrate in the convective boundary layer, Atmos. Chem. Phys., 12, 3005-3023, doi:10.5194/acp-12-3005-2012, 2012.

Asman, W. A. H., Sutton, M. A., and Schjørring, J. K.: Ammonia: emission, atmospheric transport and deposition, New Phytol., 139, 27-48, doi:10.1046/j.1469-8137.1998.00180.x, 1998.

Butterbach-Bahl, K., Gundersen, P., Ambus, P., Augustin, J., Beier, C., Boeckx, P., Dannenmann, M., Gimeno, B. S., Ibrom, A., Kiese, R., Kitzler, B., Rees, R. M., Smith, K. A., Stevens, C., Vesala, T., and Zechmeister-Boltenstern, S.: Nitrogen processes in terrestrial ecosystems, in: The European Nitrogen Assessment, edited by: Sutton, M. A., Howard C. M., Erisman, J. W., Billen, G., Bleeker, A., Grennfelt, P., van Grinsven, H., and Grizzetti, B., Cambridge University Press, Cambridge Books Online, 99-125, doi:10.1017/CBO9780511976988.009, 2011.

Cape, J. N.: Operation of EMEP "supersites" in the United Kingdom, Annual report for 2007, ISBN: 978-1-906698-157, available at: http://nora.nerc.ac.uk/8660/2/EMEP_supersite report_2007N008660CR.pdf, 2009.

Corbett, J. J., Fischbeck, P. S., and Pandis, S. N.: Global nitrogen and sulfur inventories for oceangoing ships, J. Geophys. Res., 104, 3457-3470, doi:10.1029/1998jd100040, 1999.

Corbett, J. J., Lack, D. A., Winebrake, J. J., Harder, S., Silberman, J. A., and Gold, M.: Arctic shipping emissions inventories and future scenarios, Atmos. Chem. Phys., 10, 9689-9704, doi:10.5194/acp-10-9689-2010, 2010.

Draxler, R. and Hess, G.: An Overview of the HYSPLIT_4 modelling system for trajectories, dispersion and deposition, Aust. Met. Mag. 47, 295-308, available at: http://www.bom.gov.au/ amoj/docs/1998/draxler.pdf, 1998.

EMEP: manual for sampling and chemical analysis, Norwegian Institute for Air Research, Kjeller, EMEP/CCC-Report 1/95, Rev. 2007, available at: http://www.nilu.no/projects/ccc/manual/ index.html, 2007.

Erisman, J. W., Otjes, R., Hensen, A., Jongejan, P., van den Bulk, P., Khlystov, A., Mols, H., and Slanina, J.: Instrument development and application in studies and monitoring of ambient ammonia, Atmos. Environ., 35, 1913-1922, doi:10.1016/S13522310(00)00544-6, 2001.

EU 2008/50/EC: Directive 2008/50/EC of the European Parliament and of the Council of 21 May 2008 on ambient air quality and cleaner air for Europe, http://eur-lex.europa.eu/LexUriServ/ LexUriServ.do?uri=CELEX:32008L0050:EN:NOT, 2008.

Ferm, M.: Atmospheric ammonia and ammonium transport in $\mathrm{Eu}-$ rope and critical loads - A review, Nutr. Cycl. Agroecosys., 51, 5-17, doi:10.1023/A:1009780030477, 1998.

Finlayson-Pitts, B. J. and Pitts, J. N.: Chemistry of the upper and lower atmosphere: theory, experiments and application, Academic Press, San Diego, CA (ISBN: 0-12-257060-x), 2000.
Fisseha, R., Dommen, J., Gutzwiller, L., Weingartner, E., Gysel, M., Emmenegger, C., Kalberer, M., and Baltensperger, U.: Seasonal and diurnal characteristics of water soluble inorganic compounds in the gas and aerosol phase in the Zurich area, Atmos. Chem. Phys., 6, 1895-1904, doi:10.5194/acp-6-1895-2006, 2006.

Godri, K. J., Evans, G. J., Slowik, J., Knox, A., Abbatt, J., Brook, J., Dann, T., and Dabek-Zlotorzynska, E.: Evaluation and application of a semi-continuous chemical characterization system for water soluble inorganic $\mathrm{PM}_{2.5}$ and associated precursor gases, Atmos. Meas. Tech., 2, 65-80, doi:10.5194/amt-2-652009, 2009.

Gutzwiller, L., Arens, F., Baltensperger, U., Gäggeler, H. W., and Ammann, M.: Significance of Semivolatile Diesel Exhaust Organics for Secondary HONO Formation, Environ. Sci. Technol., 36, 677-682, doi:10.1021/es015673b, 2002.

Heinzerling, D.: Automation of HYSPLIT trajectory generation and subsequent analysis, Washington university, Research for Undergraduates Program 2004, HYSPLIT-web, ARL Air Resources Laboratory: HYSPLIT - Hybrid Single Particle Lagrangian Integrated Trajectory Model, http://ready.arl.noaa.gov/HYSPLIT. php, 2004.

Järvi, L., Hannuniemi, H., Hussein, T., Junninen, H., Aalto, P. P., Hillamo, R., Mäkelä, T., Keronen, P., Siivola, E., Vesala, T., and Kulmala, M.: The urban measurement station SMEAR III: Continuous monitoring of air pollution and surface-atmosphere interactions in Helsinki, Finland, Boreal Environ. Res., 14, 86-109, 2009.

Jayne, J. T., Leard, D. C., Zhang, X., Davidovits, P., Smith, K. A., Kolb, C. E., and Worsnop, D. R.: Development of an aerosol mass spectrometer for size and composition analysis of submicron particles, Aerosol Sci. Tech., 33, 49-70, 2000.

Jimenez, J. L., Jayne, J. T., Shi, Q., Kolb, C. E., Worsnop, D. R., Yourshaw, I., Seinfeld, J.H., Flagan, R. C., Zhang, X., Smith, K. A., Morris, J. W., and Davidovits, P.: Ambient aerosol sampling using the Aerodyne Aerosol Mass Spectrometer, J. Geophys Res., 108, 8425, doi:10.1029/2001JD001213, 2003.

Khlystov, A., Wyers, G. P., and Slanina, J.: The Steam-Jet Aerosol Collector, Atmos. Environ., 29, 2229-2234, 1995.

Kirkby, J., Curtius, J., Almeida, J., Dunne, E., Duplissy, J., Ehrhart, S., Franchin, A., Gagné, S., Ickes, L., Kürten A., Kupc, A., Metzger, A., Riccobono, F., Rondo, L., Schobesberger, S., Tsagkogeorgas, G., Wimmer, D., Amorim, A., Bianchi, F., Breitenlechner, M., David, A., Dommen, J., Downard, A., Ehn, M., Flagan, R. C., Haider, S., Hansel, A., Hauser, D., Jud, W., Junninen, H., Kreissl, F., Kvashin, A., Laaksonen, A., Lehtipalo, K., Lima, J., Lovejoy, E. R., Makhmutov, V., Mathot, S., Mikkilä, J., Minginette, P., Mogo, S., Nieminen, T., Onnela, A., Pereira, P., Petäjä, T., Schnitzhofer, R., Seinfeld, J. H., Sipilä, M., Stozhkov, Y., Stratmann, F., Tomé A., Vanhanen, J., Viisanen, Y., Vrtala, A., Wagner, P. E., Walther, H., Weingartner, E., Wex, H., Winkler, P. M., Carslaw, K. S., Worsnop, D. R., Baltensperger, U., and Kulmala, M.: Role of sulphuric acid, ammonia and galactic cosmic rays in atmospheric aerosol nucleation, Nature, 476, 429-433, doi:10.1038/nature10343, 2011.

Knipping, E. and Dabdub, D.: Impact of Chlorine Emissions from Sea-Salt Aerosol on Coastal Urban Ozone, Environ. Sci. Technol., 37, 275-284, doi:10.1021/es025793z, 2003.

Kurtenbach, R., Becker, K. H., Gomes, J. A. G., Kleffmann, J., Lorzer, J. C., Spittler, M., Wiesen, P., Ackermann, R., Geyer, A., 
and Platt, U.: Investigations of emissions and heterogeneous formation of HONO in a road traffic tunnel, Atmos. Environ., 35, 3385-3394, doi:10.1016/S1352-2310(01)00138-8, 2001.

Lipfert, F. W.: Filter Artifacts Associated with Particulate Measurements - Recent-Evidence and Effects on Statistical Relationships, Atmos. Environ., 28, 3233-3249, 1994.

Makkonen, U. et al.: Seasonal cycles of water-soluble ions and gases at a boreal forest site in Finland, in preparation, 2012.

Mosier, A. R.: Exchange of gaseous nitrogen compounds between agricultural systems and the atmosphere, Plant Soil, 228, 17-2, 10.1023/A:1004821205442, 2001.

Mulik, J. and Sawicki, E.: Ion chromatography, Environ. Sci. Technol., 13, 804-809, doi:10.1021/es60155a014, 1979.

Mulik, J., Puckett, R., Williams, D., and Sawicki, E.: Ion chromatographic analysis of sulfate and nitrate in ambient aerosols, Anal. Lett., 9, 653-663, doi:10.1080/00032717608059128, 1976.

Nie, W., Wang, T., Gao, X., Pathak, R.K., Wang, X., Gao, R., Zhang, Q., Yang, L., and Wang, W. X.: Comparison among filter-based, impactor-based and continuous techniques for measuring atmospheric fine sulfate and nitrate, Atmos. Environ., 44, 4396-4403, doi:10.1016/j.atmosenv.2010.07.047, 2010.

Orsini, D., Ma, Y., Sullivan, A., Sierau, B., Baumann, K., and Weber, R.: Refinements to the Particle-Into-Liquid Sampler (PILS) for Ground and Airborne Measurements of Water Soluble Aerosol Composition, Atmos. Environ., 37, 1243-1259, doi:10.1016/S1352-2310(02)01015-4, 2003.

Ruoho-Airola, T., Leppänen, S., and Makkonen, U.: Changes in the concentration of reduced nitrogen in the air in Finland between 1990 and 2007, Boreal Environ. Res., 15, 427-436, 2010.

Schaap, M., Otjes, R. P., and Weijers, E. P.: Illustrating the benefit of using hourly monitoring data on secondary inorganic aerosol and its precursors for model evaluation, Atmos. Chem. Phys., 11, 11041-11053, doi:10.5194/acp-11-11041-2011, 2011.

Seinfeld, J. H. and Pandis, S. N.: Atmospheric Chemistry and Physics: From Air Pollution to Climate Change, J. Wiley, New York, 1998.

Slanina, J., ten Brink, H. M., Otjes, R. P., Even, A., Jongejan, P., Khlystov, S., Waijers-Ijpelaan, A., Hu, M., and Lu, Y.: The continuous analysis of nitrate and ammonium in aerosols by the steam jet aerosol collector (SJAC): extension and validation of the methodology, Atmos. Environ., 35, 2319-2330, doi:10.1016/S1352-2310(00)00556-2, 2001.

Stern, D. I.: Global sulfur emissions from 1850 to 2000, Chemosphere, 58, 163-175, 2005.

Stevens, R. K., Dzubay, T. G., Russwurm, G., and Rickel, D.: Sampling and analysis of atmospheric sulfates and related species, Atmos. Environ., 12, 55-68, doi:10.1016/0004-6981(78)901889, 1978.

Sullivan, A. P., Weber, R. J., Clements, A. L., Turner, J. R., Bae, M. S., and Schauer, J. J.: A method for on-line measurement of watersoluble organic carbon in ambient aerosol particles: Results from an urban site, Geophys. Res. Lett., 31, L13105, doi:10.1029/2004GL019681, 2004.

ten Brink, H. M., Otjes, R., Jongejan, P., and Slanina, J.: An instrument for semi-continuous monitoring of the size-distribution of ammonium nitrate aerosol, Atmos. Environ. 41, 2768-2779, doi:10.1016/j.atmosenv.2006.11.041, 2007.
Timonen, H., Saarikoski, S., Tolonen-Kivimäki, O., Aurela, M., Saarnio, K., Petäjä, T., Aalto, P. P., Kulmala, M., Pakkanen, T., and Hillamo, R.: Size distributions, sources and source areas of water-soluble organic carbon in urban background air, Atmos. Chem. Phys., 8, 5635-5647, doi:10.5194/acp-8-5635-2008, 2008.

Trebs, I., Meixner, F. X., Slanina, J., Otjes, R., Jongejan, P., and Andreae, M. O.: Real-time measurements of ammonia, acidic trace gases and water-soluble inorganic aerosol species at a rural site in the Amazon Basin, Atmos. Chem. Phys., 4, 967-987, doi:10.5194/acp-4-967-2004, 2004.

Trebs, I., Andreae, M. O., Elbert, W., Mayol-Bracero, O. L., SotoGarcía, L. L., Rudich, Y., Falkovich, A. H., Maenhaut, W., Artaxo, P., Otjes, R., and Slanina, J..: Aerosol inorganic composition at a tropical site: discrepancies between filter-based sampling and a semi-continuous method, Aerosol Sci. Technol., 4, 255-269, doi:10.1080/02786820801992899, 2008.

Vakkari, V., Laakso, H., Kulmala, M., Laaksonen, A., Mabaso, D., Molefe, M., Kgabi, N., and Laakso, L.: New particle formation events in semi-clean South African savannah, Atmos. Chem. Phys., 11, 3333-3346, doi:10.5194/acp-11-3333-2011, 2011.

Vestreng, V., Myhre, G., Fagerli, H., Reis, S., and Tarrasón, L.: Twenty-five years of continuous sulphur dioxide emission reduction in Europe, Atmos. Chem. Phys., 7, 3663-3681, doi:10.5194/acp-7-3663-2007, 2007.

von Bobrutzki, K., Braban, C. F., Famulari, D., Jones, S. K., Blackall, T., Smith, T. E. L., Blom, M., Coe, H., Gallagher, M., Ghalaieny, M., McGillen, M. R., Percival, C. J., Whitehead, J. D., Ellis, R., Murphy, J., Mohacsi, A., Pogany, A., Junninen, H., Rantanen, S., Sutton, M. A., and Nemitz, E.: Field inter-comparison of eleven atmospheric ammonia measurement techniques, Atmos. Meas. Tech., 3, 91-112, doi:10.5194/amt-3-91-2010, 2010.

Weber, R. J., Orsini, D., Daun, Y., Lee, Y.-N., Klotz, P. J., and Brechtel, F.: A Particle into-Liquid Collector for Rapid Measurement of Aerosol Bulk Chemical Composition, Aerosol Sci. Technol. 35, 718-727, doi:10.1080/02786820152546761, 2001.

Wittig, A. E., Takahama, S., Khlystov, A. Y., Pandis, S. N., Hering, S., Kirby, B., and Davidson, C.: Semi-continuous $\mathrm{PM}_{2.5}$ inorganic composition measurements during the Pittsburgh air quality study, Atmos. Environ., 38, 3201-3213, 2004.

Wolff, V., Trebs, I., Ammann, C., and Meixner, F. X.: Aerodynamic gradient measurements of the $\mathrm{NH}_{3}-\mathrm{HNO}_{3}-\mathrm{NH}_{4} \mathrm{NO}_{3}$ triad using a wet chemical instrument: an analysis of precision requirements and flux errors, Atmos. Meas. Tech., 3, 187-208, doi:10.5194/amt-3-187-2010, 2010.

Wu, W. S. and Wang, T.: On the performance of a semi-continuous $\mathrm{PM}_{2.5}$ sulphate and nitrate instrument under high loadings of particulate and sulphur dioxide, Atmos. Environ., 41, 54425451, 2007.

Wyers, G. P., Otjes, R. P., and Slanina, J.: A continuous flow denuder for the measurement of ambient concentrations and surface fluxes of $\mathrm{NH}_{3}$, Atmos. Environ., 27A, 2085-2090, doi:10.1016/0960-1686(93)90280-C, 1993. 